IZA DP No. 6494

The Equality Multiplier:

How Wage Setting and Welfare Spending

Make Similar Countries Diverge

Erling Barth

Karl Ove Moene

April 2012 


\title{
The Equality Multiplier: How Wage Setting and Welfare Spending Make Similar Countries Diverge
}

\author{
Erling Barth \\ Institute for Social Research \\ and IZA \\ Karl Ove Moene \\ University of Oslo \\ Discussion Paper No. 6494 \\ April 2012 \\ IZA \\ P.O. Box 7240 \\ 53072 Bonn \\ Germany \\ Phone: +49-228-3894-0 \\ Fax: +49-228-3894-180 \\ E-mail: iza@iza.org
}

\begin{abstract}
Any opinions expressed here are those of the author(s) and not those of IZA. Research published in this series may include views on policy, but the institute itself takes no institutional policy positions.

The Institute for the Study of Labor (IZA) in Bonn is a local and virtual international research center and a place of communication between science, politics and business. IZA is an independent nonprofit organization supported by Deutsche Post Foundation. The center is associated with the University of Bonn and offers a stimulating research environment through its international network, workshops and conferences, data service, project support, research visits and doctoral program. IZA engages in (i) original and internationally competitive research in all fields of labor economics, (ii) development of policy concepts, and (iii) dissemination of research results and concepts to the interested public.
\end{abstract}

IZA Discussion Papers often represent preliminary work and are circulated to encourage discussion. Citation of such a paper should account for its provisional character. A revised version may be available directly from the author. 


\section{ABSTRACT}

\section{The Equality Multiplier: How Wage Setting and Welfare Spending Make Similar Countries Diverge*}

The complementarity between wage setting and welfare spending can explain how almost equally rich countries differ in economic and social equality among their citizens. More wage equality increases the welfare generosity via political competition in elections. A more generous welfare state fuels wage equality via an empowerment of weak groups in the labor market. Together the two effects generate a cumulative process that adds up to a social multiplier explaining how equality multiplies. Using data on 18 OECD countries over the period 1976-2002 (determined by the availability of the generosity index of welfare spending) we test the main predictions of the model and identify a sizeable magnitude of the equality multiplier. We obtain additional support by using spending data to extend the panel up to 2007 , and by applying another data set for the US over the period 1945-2001.

JEL Classification: $\quad H 53, \mathrm{I31}, \mathrm{J} 31$

Keywords: $\quad$ welfare state, wage inequality

Corresponding author:

Erling Barth

Institute for Social Research

P.box 3233

Elisenberg

0208 Oslo

Norway

E-mail: eba@socialresearch.no

\footnotetext{
* This work is part of a larger research project at ESOP, University of Oslo, The Frisch Center, and the Institute for Social Research, Oslo. We are grateful for comments by Jon Fiva, Jeff Frieden, Steinar Holden, Torben Iversen, Jo Thori Lind, Ragnar Nymoen, Atle Seierstad, Fredrik Willumsen and for valuable research assistance by Esther Ann Nisja Bøler. Research Grants from the Research Council of Norway, grant number 168 285/S20, are gratefully acknowledged. Erling Barth thanks the Labor and Worklife Program at Harvard University and the National Bureau of Economic Research for their generosity and hospitality during his work with this paper.
} 


\section{Introduction}

Equally rich countries differ hugely in their income distribution and welfare spending, and the largest welfare states are systematically found in countries with the smallest differences in gross earnings. In spite of a clear pattern, there is no consensus on how to explain it.

For instance, compared to the United States the Scandinavian countries of Denmark, Norway and Sweden, have twice as generous welfare spending, but only half of the US pre tax wage inequality. Some influential papers explain the stark US-Scandinavian difference by pointing to America's racial heterogeneity (Alesina, Glaeser and Sacerdote 2001), to more social homogeneity in Europe and an extraordinary Scandinavian commitment to equality (Therborn 1986), and to the possibility of one distinct European equilibrium and one distinct US equilibrium in terms of perceptions of the relative impact of luck versus compensation for effort (Alesina and Angeletos 2005).

The pattern seems to be more general, however. The negative correlation between pre tax inequality and welfare spending holds for almost any sub-group of the developed countries. ${ }^{1}$ It is also visible within countries over time. In the US, for instance, periods with less growth in wage differentials have had higher growth in welfare generosity, and vice versa. Social spending increased sharply as a share of GDP during the 1940's, following president Roosevelt's Social Security Act of 1935, while pre tax wage inequality dropped to the extent that Claudia Goldin and Robert Margo (1992) labeled the period the "Great Compression". In contrast, during the 1980's there was an unprecedented rise in wage inequality and a marked retrenchment in social spending. ${ }^{2}$

Below we suggest a simple explanation for the negative associations between wage inequality and welfare spending over time and across countries that is meant to cover both the US-Europe divide and the divisions within Europe. In our framework the distribution of wages depends on the distribution of the productivity of jobs and of the generosity of welfare benefits, while the political support for welfare spending depends on the wage distribution. Thus welfare spending is both fueled by and fuels wage equality.

The equality magnifying effect, captures how voters react to more wage equality and how the political competition picks it up. More wage equality for a given mean, implies that the wage earners below the mean (the majority of voters) become richer. In our account voters consider the welfare state a provider of normal goods, for instance social insurance, the demand for which goes up with individual incomes. In addition the individual political demand for welfare spending depends on the vulnerability for shocks and

\footnotetext{
${ }^{1}$ For the US-Europe comparison Alesina and Glaeser 2004 offer an excellent discussion; for cross country discussions more generally, see for instance Mianovic 2000, Moene and Wallerstein 2001, Lindert 2004, and the overview by Lind 2005.

${ }^{2}$ For the development in the US over time see for instance Moffitt, Ribar and Wilhelm 1998, Lee and Roemer 2006, and the overview by Levy and Murnane 1992.
} 
for the loss of income and health. When a majority of voters obtain higher wages for a given distribution of risks and shocks, they therefore demand more, not less, welfare generosity. Political parties pick this up to improve their chances to win elections, but as they trade off ideology against winning chances, their suggested policies do not converge and the implemented generosity depends on which party wins.

The wage equalizing effect captures how welfare benefits make low paid workers less vulnerable and better protected, as their necessities become less immediate, and thus improve their bargaining position and their ability to demand a better pay. In this way it weakens the direct link between the productivity distribution across jobs and the wage distribution across workers. By raising the lowest wages the wage equalizing effect reduces wage inequality from below.

The two effects are complementary and enhance structural and institutional differences across countries related to history, size, resources, and institutions, magnifying changes over time. Together they generate a cumulative process where a more equal wage distribution fuels welfare generosity, and a more generous welfare state fuels wage equality, adding up to a sizable social multiplier. ${ }^{3}$ The process can also go in reverse, as it has done in many countries since the mid 1980s. It then generates an inequality multiplier where larger wage differences induce less welfare generosity, and in turn larger wage differences, and so on.

The mechanisms that we emphasize, are more general than the model that we offer to make them precise. The premiss for for set up is that voters do not consider the welfare state a machinery for pure redistribution. The equality magnifying effect applies as long as the basic welfare state provisions are normal goods for income earners below the average incomes, holding the distribution of other group characteristics constant. In the model we capture this by deriving the support for welfare spending from strong social insurance motives. This captures how protection against risks historically has been more universally sought, and has been more important for the expansion of the welfare state, than pure redistribution of resources (Baldwin 1990, Barr 1992). Even though not all welfare spending relates to insurance, it is clear that social insurance against loss of income due to sickness, unemployment, and old age, reacts more to changes in the income distribution than other types of public spending (Moene and Wallerstein, 2003).

To capture the support for welfare spending and the distribution of wages in a common framework we also incorporate the flows in and out of jobs with different productivity in a simplistic manner, highlighting exogenous separations between firms and workers. More productive workers face lower risks of loss of income and jobs, establishing a negative correlation between income and risks.

\footnotetext{
${ }^{3}$ Glaeser, Sacerdote and Scheinkman (2003) discuss social multipliers where individual behavior depends on aggregate behaviors. In our case the complementarity is between institutions of the labor market and the welfare state.
} 
This 'lower income higher risk' assumption is consistent with unemployment rates being higher among low skilled than high skilled workers, as they are throughout the OECD area. In 2009, for instance, the average unemployment rate of the OECD countries was 12 percent for men with Lower Secondary education and only and 5.5 for men with Tertiary education (OECD 2011). ${ }^{4}$ The more flexible wage structure in the US produces a similar pattern of low income risks: "The job loss rates are dramatically higher for less educated workers than for more educated workers. For example, the job loss rate for workers with twelve years of education was 9.4 percent in 1997-99 compared with 14.3 percent in 1981-83 and 19.4 percent in 2007-2009. In contrast the job-loss rate for workers with at least 16 years of education was 5.4 percent in 1987-1989 compared with 6.9 percent in 1981-1983 and 11 percent in 2007-2009." (Farber 2011, p. 6) ${ }^{5}$

The negative correlation between income and risks in our model helps explain why the rich is less in favor of welfare spending than the poor, making welfare spending an inferior good as we move from lower to higher income classes. Thus richer income classes tend to vote for less welfare than poorer income classes. Yet, for a given distribution of risks a mean preserving compression of wage differentials raises the incomes of voters below the mean and their political support for welfare spending.

Empirically it is not easy to clearly identify the equality magnifying effect and wage equalizing effect and thus to quantify the equality multiplier. The main results that we offer are based on data from 18 OECD countries over 26 years suggest an average equality multiplier of about 1.5 using different instrumental variable approaches, including country fixed effects. If this is accurate, any initial change, or structural difference, is magnified by more than fifty percent due to the feedback effects. We also offer some supporting evidence by taking a closer look at the development of welfare spending and wage inequality in the US after World War II (using a different data set). The US is a particularly interesting example since it represents an important extreme case with high wage dispersion and low welfare generosity.

Inspired by Roland Benabou (2000), our paper follows Alberto Alesina and GeorgeMarios Angeletos (2005) (and the extension in Alesina, Cozzi and Mantovan 2009, and in Di Tella and Dubra 2010) in highlighting the mutual two-ways dependence between welfare spending and gross earnings inequality. While they explain the support for welfare spending by the perceived fairness of redistributive policies, we emphasize the related insurance motive. While they stress how the welfare state may hamper human capital

\footnotetext{
${ }^{4}$ For Norway, Bratsberg, Fevang and Røed (2010) find that the log odds ratio of college educated male employees of becoming disabled is significantly lower: .926 (bachelor) and 1.215(graduate level), than for similar male employees with compulsory education only, even after controlling for a host of individual and workplace characteristics

${ }^{5}$ Young workers are also found to have significantly higher job-loss rates than older workers. Farber (2011) also finds important differences in post-displacement careers across educational groups: "..the likelihood of post-displacement employment rises with education while there is a negative relationship between post-displacement unemployment and education."(p.10).
} 
investments, compressing the distribution of earnings from above, we emphasize how welfare benefits empower weak groups compressing the wage distribution from below.

Our insistence on a negative association between pre tax inequality and welfare spending, contrasts the classical view on redistribution by Thomas Romer (1975), Kevis Roberts (1977) and Allan Meltzer and Scott Richards (1981). Their prediction that higher pre tax inequality should induce higher redistribution is not supported by empirical studies such as the broad historical accounts by Peter Lindert (2004), the historical evidence across US counties and states by Rodneu Ramcharan (2010), and the comprehensive cross country studies by Roberto Perotti $(1993,1996)$ to mention a few central works.

We add the reverse linkage to the analysis of how wage equality fuels the political demand for normal welfare state provisions, such as social insurance against loss of income (as discussed in Moene and Michael Wallerstein 2001, and Torben Iversen and David Soskice 2001), echoing de Toqueville's link between 'public spirit' and the 'habits to the governed' (Toqueville 1835, ch 1). We also incorporate elements of Gösta EsbingAndersen's (1990) classifications of welfare states, and the role of openness and country size emphasized by David Cameron (1978), Peter Katzenstein (1985), and Dani Rodrik (1997).

Finally, the cumulative changes across institutions connect our paper to the recent discussion of why seemingly similar countries sustain widely differing wage structures and have different developments of wage inequality over time (see eg. Devroye and Freeman 2001; DiNardo, Fortin, and Lemieux 1996; Leuven, Oosterbeek, and van Ophem 2004; Kahn 2000; Blau and Kahn 1996; Acemoglu 2003; Scheve and Stasavage 2008; Katz and Murphy 1992; Card and DiNardo 2002; Katz and Autor 1999; Autor, Katz, and Kearney 2008; Goldin and Katz 2007).

After presenting our model of the equality multiplier (in section 2), we turn to the empirical analysis (in sections 3, 4, and 5), and conclude (in section 6).

\section{Model}

We use a political economy set-up of probabilistic voting with ideological parties (see Persson and Tabellini 2000, and Roemer 2001). Voters are distributed over occupations with different incomes and different vulnerability for job loss. The analysis is framed within a simple version of the Diamond-Mortensen-Pissarides model of segregated labor markets (see Pissarides 2000). Within this framework we derive i) voters' interests in welfare policies, ii) the links between party policies and winning chances in elections,

and iii) employers' and employees' interests in wage negotiations. While i) and ii) are important for the discussion of the equality magnifying effect, iii) determines the wage equalizing effect. 


\section{Policies and political competition}

There are two parties or blocks, the left and the right, that differ in their ideologies in the traditional manner. The party preferences over policy outcomes are written as $W_{L}(G)$ and $W_{R}(G)$ where $G$ indicates the generosity of the welfare state. At least for intermediate values of generosity the left prefers a higher generosity and the right a lower generosity as $W_{L}^{\prime}(G)>0$ and $W_{R}^{\prime}(G)<0$. The left proposes $G_{L}$ and the right proposes $G_{R}$.

In determining the party programs each party is willing to compromise somewhat on ideology in order to improve the chances of winning the election. They are interested in maximizing the expected value of their party utilities, defined by

$$
\begin{aligned}
& P_{L}=q W_{L}\left(G_{L}\right)+[1-q] W_{L}\left(G_{R}\right) \\
& P_{R}=[1-q] W_{R}\left(G_{R}\right)+q W_{R}\left(G_{L}\right)
\end{aligned}
$$

In these expressions $q=q\left(G_{L}, G_{R}\right)$ is the probability that the left wins, which is declining in both its arguments, and $(1-q)$ is the probability that the right wins. How these probabilities are derived is explained shortly.

The policies of each party are determined before the elections. Each political party takes the pre tax distribution of income for given and is required to balance the budget. The Nash equilibrium of the policy game are given by the first order conditions

$$
\begin{array}{r}
\frac{\partial q\left(G_{L}, G_{R}\right)}{\partial G_{L}}\left[W_{L}\left(G_{L}\right)-W_{L}\left(G_{R}\right)\right]+q\left(G_{L}, G_{R}\right) \frac{\partial W_{L}}{\partial G_{L}}=0 \\
-\frac{\partial q\left(G_{L}, G_{R}\right)}{\partial G_{R}}\left[W_{R}\left(G_{R}\right)-W_{R}\left(G_{L}\right)\right]+\left(1-q\left(G_{L}, G_{R}\right)\right) \frac{\partial W_{R}}{\partial G_{R}}=0
\end{array}
$$

where the left party chooses $G_{L}>G_{R}$ such that the marginal reduction in the chance of winning the election times the gain of winning $\left[W_{L}\left(G_{L}\right)-W_{L}\left(G_{R}\right)\right]$, just equals the marginal ideological gain of running with a policy closer to the party's ideals, and the right party chooses $G_{R}<G_{L}$ such that the marginal reduction in the chance of winning the election times the gain of winning $\left[W_{R}\left(G_{R}\right)-W_{R}\left(G_{L}\right)\right]$, equals the marginal ideological gain of running with a policy closer to the party's ideals.

With completely opportunistic parties that do not care about which policies they run on, policies would converge to $G_{L}=G_{R}=G^{*}$. When policies do matter, it pays for the left to deviate from $G^{*}$ by setting a higher level of $G_{L}$. By so doing the marginal ideological gain $q \partial W_{L} / \partial G_{L}$ is strictly positive. By increasing the level of $G_{L}$, the left party's chance of winning the election declines and $\partial q / \partial G_{L}<0$. Similarly, the right party would deviate from $G^{*}$ by reducing the level of $G_{R}$ in the direction of the party's ideal policy. 


\section{Workers as voters}

Workers belong to different income classes. The pre-tax distribution of income depends on the distribution of productivity across jobs. To fill a job workers need specific qualifications. Workers of type $p$ only qualify for $p$-jobs where $p$ is an element in the discrete distribution $\left(p_{1} \leq p_{2}, \leq \ldots \leq p_{T}\right)$. Higher $p$ values indicate higher earnings and thus higher income classes as we shall make clear below.

Workers also differ in their risks of income loss. To show how these differences can play out we concentrate on unemployment risks and model the flows in and out of unemployment. ${ }^{6}$ The risks of reemployment once unemployed depend on the number of matches of vacant jobs and idle workers, which again depends on the number of vacancies relative to the number of unemployed workers - the tightness of the labor market $\theta_{p}$. The number of matches is a declining function of that tightness, $m\left(\theta_{p}\right) \equiv m_{p}$. During the short time interval $d t$ a vacant position is filled with a probability $m_{p} d t$ implying the probability of getting a job for an unemployed worker must be the number of matches multiplied by the tightness of the labor market, $m_{p} \theta_{p} d t$.

The probability of job loss is important for both welfare spending and wage setting. We assume that there is an exogenous separation rate $\lambda_{p}$ in jobs of type $p$, and in line with the empirical evidence discussed in the introduction, that lower productivity jobs have a higher turnover, implying that $\lambda_{p}$ is decreasing in $p$ in accordance with this lowerincome-higher-risk assumption. It is important though that risks are associated not with income per see, but with qualifications and the job as captured by $p$.

Throughout we focus on a steady state where the flow of workers from unemployment into jobs equals the flow of workers out of jobs and into unemployment in each segregated labor market. Thus with an unemployment rate $u_{p}$ we have

$$
\theta_{p} m_{p} u_{p}=\lambda_{p}\left(1-u_{p}\right)
$$

The size of income class $p$ is $n_{p}$, and the size of the workforce and the electorate is normalized to unity, implying that $\sum n_{p}=1$

\section{Voters' interests}

During the election period, welfare policies remain fixed. Each voter, however, can go in and out of states of employment and unemployment many times during this period. We capture this by continues streams of job separation and job creation. Each voter has a concave utility function $U\left(c_{p}\right)$ of consumption $c_{p}$ with a constant coefficient of relative

\footnotetext{
${ }^{6}$ In addition we could easily incorporate loss of income due to sickness and ill health by distinguishing between the unemployed and the sick among those who are not working.
} 
risk aversion $\mu>1$, and the stream of future utilities depends on the welfare spending.

As we proceed we consider welfare spending as insurance against income loss. The resulting insurance logic may also hold in the case where we in addition to social insurance also add redistribution among the employed (Moene and Wallerstein, 2001). Below the generosity of the welfare state $G$ represents a common compensation in the event of income loss due to unemployment. That all citizens obtain the same compensation, $g_{p}=G$, is of course an oversimplified representation of the fact that social insurance in most welfare systems is offered on better terms for lower income classes than for higher. It can easily be generalized, but only at the cost of more notation. ${ }^{7}$

Jobs are treated as assets. The return on the asset equals the stream of utility minus the expected asset loss. The present value of the expected utility stream is $V_{p}^{e}$ for an employed, and $V_{p}^{u}$ for a worker who starts out without a job. The values are implicitly defined by

$$
\begin{aligned}
& r V_{p}^{e}=U\left(c_{p}\right)-\lambda_{p}\left[V_{p}^{e}-V_{p}^{u}\right] \\
& r V_{p}^{u}=U(G)+\theta_{p} m_{p}\left[V_{p}^{e}-V_{p}^{u}\right]
\end{aligned}
$$

where $r$ is the discount rate. In these expressions $g_{p}$ is the income of an unemployed worker, determined by the generosity of the welfare state.

Solving (6) and (7) we obtain

$$
\begin{array}{ll}
r V_{p}^{e}=\gamma_{p} U\left(c_{p}\right)+\left(1-\gamma_{p}\right) U(G) & \text { where } \gamma_{p}=\frac{r+\theta_{p} m_{p}}{r+\lambda_{p}+\theta_{p} m_{p}}<1 \\
r V_{p}^{u}=\tilde{\gamma}_{p} U\left(c_{p}\right)+\left(1-\tilde{\gamma}_{p}\right) U(G) & \text { where } \tilde{\gamma}_{p}=\frac{\theta_{p} m_{p}}{r+\lambda_{p}+\theta_{p} m_{p}}<1
\end{array}
$$

The weight put on the state of unemployment is higher for an unemployed worker than an employed. For both the employed and unemployed this weight is increasing in the rate of job separation $\lambda_{p}$. The higher vulnerability of lower income classes implies a higher weight on the unemployment state, $\left(1-\gamma_{p}\right)$, both because of the direct impact and because (we can show that) a higher rate job separation reduces the tightness of the labor market and

\footnotetext{
${ }^{7}$ In general, some benefits are proportional to present earnings or past contributions; others are not. We could have incorporated this by a given parameter $\xi \in(0,1]$ reflecting the composition of welfare spending and the extent to which the poor are offered social insurance on better terms than the rich:

$$
\tilde{g}_{p}=\left(\xi+(1-\xi) \frac{w_{p}}{\bar{w}}\right) G
$$

The benefits $G$ (the benefit level to workers with the average wage) of the social insurance scheme are distributed with a fixed component common to all and a variable component that depends on past and present contributions. The fixed component is $\xi G$ which defines the floor of welfare benefits to people without income. The variable component is proportional to income relative to the mean $G(1-\xi) w_{p} / \bar{w}$, implying that here $g_{p}$ is the welfare benefits to a worker of type $p$ in the event of income loss. The higher is $\xi$, the more redistributive are the terms of the social insurance scheme. In the presentation we apply the simplifying assumption that $\xi=1$.
} 
thus reduces the rate of reemployment as $d \theta_{p} m\left(\theta_{p}\right) / d \lambda_{p}<0$.

With a tax rate equal to $t$ and the tax base $\sum\left(1-u_{p}\right) n_{p} w_{p}$, the balanced budget condition can be represented by

$$
t=b G \quad \text { where } b=\frac{\sum n_{p} u_{p}}{\sum n_{p}\left(1-u_{p}\right) w_{p}}
$$

Each voter incorporates the correct equilibrium value of $b$ in calculating his ideal policy.

Inserting $c_{p}=(1-b G) w_{p}$ in the expression of $V_{p}^{e}$ and $V_{p}^{u}$ we write $V_{p}^{e}(G)$ (and $V_{p}^{u}(G)$ ) and the ideal policy of (the employed members of) group $p$ is $G_{p}^{*}=\arg \max V_{p}^{e}(G)$. The first order condition is

$$
-U^{\prime}\left(c_{p}\right) b w_{p}+h_{p} U^{\prime}\left(G_{p}^{*}\right)=0 \quad \text { where } h_{p} \equiv \frac{1-\gamma_{p}}{\gamma_{p}}=\frac{\lambda_{p}}{r+\theta_{p} m_{p}}
$$

The value of $h_{p}$ expresses the vulnerability of group $p$ which is higher for lower income classes both because of higher job separation rates and because of the implied slack in the labor market (lower $\theta_{p} m_{p}$ ). This observation is in line with our perception of welfare spending as an inferior good as we move up the income classes. ${ }^{8}$

Yet, our main claim about voters' interests can be summarized as

Proposition 1 Even when welfare spending is an inferior good across income classes, in the sense that the preferred level of $G_{p}^{*}$ is lower in higher income classes as their vulnerability is lower, welfare spending is a normal good within each income class, in the sense that for a given vulnerability $h_{p}$ the preferred level of $G_{p}^{*}$ goes up with the income of the members of the income class.

Proof. Welfare spending is a normal good within income classes since from the first order condition $d V_{p}^{e}(G) / d G=0$ in (11) we have

$$
\frac{d G_{p}}{d w_{p}}=\frac{(\mu-1) U^{\prime}\left(c_{p}\right) b}{-d^{2} V_{p}^{e}(G) / d G^{2}}>0
$$

as long as $\mu>1$

\section{How voters vote}

How voters cast their votes depend both on their narrow interests, given by (8) and (9), and their ideological sympathies. There is a distribution of ideological sympathies within each income class. The extent of sympathies, $\epsilon_{p}$, can take positive and negative values. Higher values mean more right-wing sympathies. In addition the popularity of parties

\footnotetext{
${ }^{8}$ To the extent that fairness norms and beliefs play a role in in the social interests of each income class these factors should be incorporated in $h_{p}$.
} 
and politicians may shift with a magnitude $\delta$ after the program is decided. With policy platforms $G_{L} \geq G_{R}$ all employed voters in income class $p$ for whom

$$
V_{p}^{e}\left(G_{L} ; w_{p}\right)-V_{p}^{e}\left(G_{R} ; w_{p}\right) \geq \epsilon_{p}+\delta
$$

tend to vote left, while all unemployed voters in income class $p$ for whom

$$
V_{p}^{u}\left(G_{L} ; w_{p}\right)-V_{p}^{u}\left(G_{R} ; w_{p}\right) \geq \epsilon_{p}+\delta
$$

tend to vote left.

To be clear let us assume that the distribution of ideological sympathies within income class $p$ is uniform on $\left[-1 / 2 f_{p}, 1 / 2 f_{p}\right]$ and similarly that the common popularity shock has an uniform distribution on $[-1 / 2 z, 1 / 2 z]$. Using the short hand

$$
\left(1-u_{p}\right) V_{p}^{e}\left(G ; w_{p}\right)+u_{p} V_{p}^{u}\left(G ; w_{p}\right) \equiv V_{p}\left(G ; w_{p}\right)
$$

the probability that the left wins can be expressed as ${ }^{9}$

$$
\left.q\left(G_{L}, G_{R}\right)=1 / 2+z \sum_{p} f_{p} n_{p}\left[V_{p}\left(G_{L} ; w_{p}\right)\right)-V_{p}\left(G_{R} ; w_{p}\right)\right]
$$

For a given density of political shocks $z$ in (13) each income groups obtains an influence on the probability of winning according to its size $n_{p}$ and its density $f_{p}$ of political sympathies. The influence weighted income can expressed as $\sum_{p} n_{p} f_{p} w_{p}$ which is proportional to the average wage if the density of political sympathies is the same across all income groups. It is proportional to the median income only in the case where all other groups than the median income group have very spread out sympathies.

In general a group of voters (rich or poor) of a a given size $n_{p}$ may have a strong influence on $q$ if the the variation of random shocks is small and thus $z$ is high, and if the group has a high density $f_{p}$ of political sympathies. The higher the density of an income group the more of its members would consider to change party when policies change. Thus the political parties can benefit from targeting policies in favor of the interests of large groups with high density. The interests of groups that are either small or highly diversified in their political sympathies tend to be neglected in the political competition.

\footnotetext{
${ }^{9}$ With $\Delta_{p}^{j}=V_{p}^{j}\left(G_{L} ; w_{p}\right)-V_{p}^{j}\left(G_{R} ; w_{p}\right)$ for $j=e, u$ we have that the expected vote share of the left is $\left.s=\sum_{p} n_{p}\left\{\left(1-u_{p}\right)\right) \int_{-1 / 2 f_{p}}^{\Delta_{p}^{e}} f_{p} d \epsilon_{p}+u_{p} \int_{-1 / 2 f_{p}}^{\Delta_{p}^{u}} f_{p} d \epsilon_{p}\right\}=\sum_{p} n_{p}\left\{\left[\left(1-u_{p}\right) \Delta_{p}^{e}+u_{p} \Delta_{p}^{u}\right] f_{p}+1 / 2\right\}$. The random popularity shock smoothens the probability around $1 / 2$, as the realized vote shares are moved to $(s-\delta)$ for the left, and $(1-s+\delta)$ for the right and the winning chance of the left becomes $\operatorname{Pr}(s-\delta>1 / 2)=\int_{-1 / 2 z}^{s-1 / 2} z d \delta=1 / 2+(s-1 / 2) z$. Inserting for $s$, gives us the expression in (13)
} 


\section{Wage determination}

Workers and employers bargain over the division of rents that arise when workers and employers are matched. Generally, the more risk averse side of the negotiations obtain the lower share of the surplus (see Osborne and Rubinstein, 1990). Thus workers have reasons to pretend to be risk neutral in the haggling over wages. To the extent that they don't succeed, the effect of their risk aversion can be captured by a lower bargaining power. In any case, to get a tractable solution to wage setting (that can be used to illustrate how different levels of coordination may lead to different wage distributions) we proceed as if workers are risk neutral in their bargaining behavior, implying that in the bargaining $U\left(c_{p}\right) \equiv w_{p}$ and $U(G) \equiv G$. In other respects the asset values of workers are given by (9) and (8).

In income class $p$ the employment rent is $V_{p}^{e}-V_{p}^{u}>0$ and the employer rent is $\Pi_{p}^{f}-\Pi_{p}^{v}$, the difference between the value of a filled vacancy and the value of an unfilled vacancy. Thus the total surplus of the match, $\Pi_{p}^{f}-\Pi_{p}^{v}+V_{p}^{e}-V_{p}^{u}>0$, is shared according to the Nash bargaining solution where workers' share (the bargaining power of income class $p$ ) is $\alpha_{p} \in(0,1)$, implying that

$$
V_{p}^{e}-V_{p}^{u}=\alpha_{p}\left[\Pi_{p}^{e}+V_{p}^{e}-\Pi_{p}^{f}-V_{p}^{u}\right]
$$

The asset values of the employers are given by

$$
r \Pi_{p}^{v}=-p s+m\left(\theta_{p}\right)\left[\Pi_{p}^{f}-\Pi_{p}^{v}\right] \quad \text { and } \quad r \Pi_{p}^{f}=p-w_{p}-\lambda_{p}\left[\left(\Pi_{p}^{f}-\Pi_{p}^{v}\right]\right.
$$

Job creation takes place till the value of a vacancy equals zero, $\Pi_{p}^{v}=0$. Using all this we obtain the simple wage equation

$$
w_{p}=\alpha_{p} p\left(1+s \theta_{p}\right)+\left(1-\alpha_{p}\right) G
$$

that demonstrates how the earnings in income class $p$ depend positively on the productivity of their jobs, the tightness $\theta_{p}$ of the labor market, the generosity of welfare benefits, and their bargaining power $\alpha_{p}{ }^{10}$

We can calculate the 'floor elasticity'

$$
\frac{d w_{p}}{d G} \frac{G}{w_{p}}=\frac{G}{G+p\left(1+s \theta_{p}\right) \alpha_{p} /\left(1-\alpha_{p}\right)} \equiv \eta_{p}
$$

\footnotetext{
${ }^{10}$ The rent sharing aspect of our simple wage equation is consistent with the empirical literature suggesting that there can be unequal pay for equal work even without unions (Krueger and Summers 1988, Groshen 1991, Gibbons and Katz 1992, Barth, Bryson, Davis, and Freeman 2010). The impact of welfare benefits on wages, our main interest, is also in line with efficiency wage mechanisms. For instance in the contested exchange version of efficiency wages by Bowles and Gintis (1993), each worker obtains an excess utility beyond the fall back position. The value of the fall back position is more sensitive for higher welfare generosity in low paid positions than in others.
} 
which is higher in lower income classes than in higher income classes as low paid jobs have both lower productivity $p$ and lower tightness $\theta_{p}$ (and most likely a lower bargaining power $\alpha_{p}$ ). Thus higher welfare spending compresses the wage distribution from below.

As we proceed we investigate the impacts of initial differences in the wage distribution. Wage compression means that the effective bargaining power of higher income classes declines, while the bargaining power of lower income classes increases. It is normally associated with coordination of collective bargaining where some worker-employer bargaining is replaced by worker-worker arguing. With a high level of coordinated wage setting, it is difficult to utilize the same type of industrial actions as in worker-employer bargaining with less coordination, strengthening the power of weak groups. Just to form a union of workers with different productivity levels implies that the union bargains on behalf of its members who in turn must have a way to distribute the total union rent between themselves. Further coordination between unions have, in fact, a stronger influence on relative wages than on the functional distribution of wages and profits (Wallerstein 1999). ${ }^{11}$

The principle seems to be that wage coordination determines the units over which fairness norms are applied. When wages are determined at the firm level, the distribution of wages are compressed within the firm. When wages are set at the industry level, the distribution of wages are compressed across firms within the industry. When wages are set at the national level, the distribution of wages are compressed across firms, industries and occupations throughout the entire nation.

\section{Equilibrium}

For a given distribution of bargaining power an equilibrium in this model basically consists of

- policies $G_{L}, G_{R}$ that solve the Nash equilibrium of the policy game in (3) and (4) subject to $(13)$

- a distribution of wages $w_{p}$ that depends on the implemented policy $G=\left\{G_{L}, G_{R}\right\}$ in accordance with (16)

We can characterize the equilibrium by the following proposition when the spread of ideological sympathies are about the same in all income classes $\left(f_{p} \approx f\right)$ :

Proposition 2 A mean preserving compression of wages raises the proposed welfare generosity of both parties - the equality magnifying effect. A more generous welfare state compresses the wage structure-the wage equalizing effect. Together the two effects generate an equality multiplier.

\footnotetext{
${ }^{11}$ See also Freeman (1991), Card (2001), and Moene and Wallerstein (1997).
} 


\section{Proof.}

See appendix A

The basic message of the proposition is that wage equality fuels welfare spending, which again fuels wage equality. The two distinct effects are tied together via a common measure of inequality.

To be clear we can measure inequality $I$ by the relative inequality between a reference wage $\tilde{w}$ (for instance the median wage) and a specific wage $w_{p}$ below the median, such that $I=\tilde{w} / w_{p}$. In accordance with proposition 2 the determination of the wage distribution can be summarized by what we denote the wage inequality equation, $I=\Psi\left(G ; y_{w}\right)$, where the vector $y_{w}$ includes such variables as per capita income, skills, risks, and wage bargaining system, and where $d I / d G=\Psi^{\prime}<0$.

Similarly, the determination of welfare spending can be summarized by what we denote the generosity equation, $G=\Phi\left(I ; y_{g}\right)$, where $y_{g}$ is a vector that includes the political party in power and other variables such as per capita income, demographics and skills, and risks, and where $d G / d I=\Phi^{\prime}<0$ in accordance with proposition 2 . This result holds when the spread of ideological sympathies are similar across income classes, implying that the influence weighted income $\sum_{p} f_{p} n_{p} w_{p}$ is proportional to the mean income $\sum_{p} n_{p} w_{p}$, allowing us to derive the impact of mean preserving changes in the wage distribution in a simple manner (in Appendix A).

Proposition 2 may, however, also hold when the (sufficient) condition that the spread of ideological sympathies is similar across income classes, does not apply. One example is the the median voter case. When that applies, a mean preserving wage compression induces higher welfare spending as the median income class experiences a raising wage, and each member would therefore vote for a more generous welfare spending (proposition 1 ). The median voter case can of course be mimicked by setting all $f_{p}$ equal to zero for all income classes accept the median income class. In general the probabilistic voting model allows for policy divergence and for the more realistic case that other groups than the median income class have an impact on the chosen policies by each party.

The multiplier can be visualized by taking total differentials of the two equations $I=\Psi\left(G ; y_{w}\right)$ and $G=\Phi\left(I ; y_{g}\right)$ to obtain

$$
\Delta G=m\left[k_{G}+\Phi^{\prime} k_{I}\right] \quad \text { and } \quad \Delta I=m\left[k_{I}+\Psi^{\prime} k_{G}\right]
$$

where $m$ is the multiplier given by $m=1 /\left(1-\Phi^{\prime} \Psi^{\prime}\right)$, and where $k_{G}$ and $k_{I}$ summarize exogenous changes in $y_{g}$ and $y_{w}$. Below we provide an example of the multiplier, using the parameters of the model.

An example: To make the example transparent we assume that the swing voters consist of members from the middle class with an income per capita below the mean 
income. This is the only group of voters considering to vote for either party depending on their proposed policies. The rest of the electorate consists of partisan voters. No party, however, can win without the support from at least half of the middle class.

The ideal policy of the middle class is denoted $G^{*}$, yielding the indirect utility $V=$ $v(w)$ if implemented. To obtain a simple closed form solution of the policy game between political parties, the preferences of the middle class can be represented by the crude approximation: $V=v(w)-(1 / 2)\left(G^{*}-G\right)^{2}$. With this approximation the probability that the left wins is

$$
q=1 / 2+z f\left[-\frac{1}{2}\left(G^{*}-G_{L}\right)^{2}+\frac{1}{2}\left(G^{*}-G_{R}\right)^{2}\right]
$$

and we have

$$
d q / d G_{L}=z f\left(G^{*}-G_{L}\right) \text { and } \quad d q / d G_{R}=-z f\left(G^{*}-G_{R}\right)
$$

The political preferences of the two parties are simply $W_{L}=A_{L}+a_{L} G$ and $W_{R}=$ $A_{R}-a_{R} G$, where $A_{i}$ and $a_{i}$ are positive constants. Inserting all these simplifications in the first order conditions (3) and (4) we can solve for the equilibrium levels

$$
G_{L}=G^{*}+\frac{1}{2 z f} \quad \text { and } \quad G_{R}=G^{*}-\frac{1}{2 z f}
$$

The distance between the two parties $\left(G_{L}-G_{R}\right)=1 /(z f)$ is smaller the higher the density of the ideological sympathies in the middle calls, $f$, and the higher the density of political shocks, $z$. Both a high $f$ and a high $z$ imply that a small change in policy can attract many middle class voters and the political competition draws the parties close to the $G^{*}$.

Since the middle class has a wage below the mean, we know from proposition 1 that $G^{*}$ goes up after a mean preserving wage compression. Accordingly, both $G_{L}$ and $G_{R}$ go up as well. To show the multiplier in this case, we need to return to the expression of the first order condition for the ideal middle class policy (11), determining $G^{*}$. We calculate

$$
\frac{d G^{*}}{d w}=\frac{(\mu-1) U^{\prime}(G) h / w}{-d^{2} V^{e}(G) / d G^{2}} \equiv k>0
$$

This should be combined with the wage equation $w=\alpha(1+s \theta) p+(1-\alpha) G_{i}$ and we can calculate

$$
d G=\frac{1}{1-k(1-\alpha)}[d\{k \alpha(1+s \theta) p\}+\tilde{y}]
$$

To see the magnitude of the multiplier $1 /(1-k(1-\alpha))$ we have to use the expression of $k$ in (22) where $-d^{2} V_{p}^{e}(G) / d G^{2}=-\left[U^{\prime \prime}\left(c_{p}\right) b^{2} w_{p}^{2}+h_{p} U^{\prime \prime}(G)\right]>-h_{p} U^{\prime \prime}(G)=h_{p} \mu U^{\prime}(G) / G$. 
Thus, by inserting that $k \equiv d G^{*} / d w<[(\mu-1) / \mu] G / w$ and from $(17)$ that $(1-\alpha) G / w \equiv \eta$ we obtain

$$
d G=m[d\{k \alpha(1+s \theta) p\}+\tilde{y}] \quad \text { where } \quad m>\frac{\mu}{\mu-\eta(\mu-1)}>1
$$

which is higher the higher is the coefficient of relative risk aversion $\mu$ and the floor elasticities of wage setting $\eta$. For instance, a coefficient of relative risk aversion $\mu=2.5$ and floor elasticities $\eta=.6$, would yield a equality multiplier as high as $m>1.5$. To see whether these magnitudes makes any sense at all we need to take a closer look at the data.

\section{How Equality Magnifies}

According to the equality magnifying effect, a more compressed pre-tax wage distribution implies a more generous welfare state. We investigate the relationship between the wage distribution and the generosity of the welfare state using 344 observations from a panel of 18 OECD countries from 1976 to 2002. Table 1 shows a regression of welfare generosity, measured by the log of the overall generosity index from the Comparative Welfare Entitlement Data Set $^{12}$, on wage inequality, measured by $\ln (\mathrm{d} 5 / \mathrm{d} 1)$ from OECD data. ${ }^{13}$ Model 1 provides OLS results without country dummies. We find higher generosity in countries with lower wage inequality, higher educational attainment, higher union density, more open economies, higher GDP per capita, and a larger share of elderly, but lower generosity in periods of right wing government. Model 2 introduces fixed country effects. Openness and union density now turns negative and insignificant, and the coefficients for the remaining covariates change somewhat in magnitude. The key result, however, is that the negative coefficient for wage inequality remains large (-.45) and significantly negative.

Model 3 shows that the coefficient for $\ln (\mathrm{d} 9 / \mathrm{d} 5)$ is not significant whereas the coefficient for $\ln (\mathrm{d} 5 / \mathrm{d} 1)$ remains unchanged when controlling for wage dispersion in the upper part of the wage distribution. In Model 4 one of the sub-categories of the overall generosity index, the Unemployment Benefit Generosity index, is used as our measure of welfare generosity. We find a negative relation also between this measure of welfare generosity and wage inequality. Even though this is the policy measure that appear to fit most closely to the generosity measure in our theoretical model, we prefer to use the overall index in the following since it is more comprehensive, including such events as sickness and disability, that would also matter for voters in an overall assessment of the generosity of the welfare state.

The final model is a fixed country effects model of the overall generosity index, where

\footnotetext{
${ }^{12}$ The Comparative Welfare Entitlement Data set is generously provided to other researchers by Professor Lyle Scruggs, University of Connecticut, see data appendix for details.

${ }^{13}$ See data appendix for details.
} 
Table 1: Welfare Generosity

\begin{tabular}{|c|c|c|c|c|c|}
\hline & Model 1 & Generosity & Model 3 & $\begin{array}{r}\text { Unempl. } \\
\text { benefit } \\
\text { Index } \\
\text { Model } 4\end{array}$ & $\begin{array}{r}\text { Generosity } \\
\text { IV } \\
\text { Model } 5\end{array}$ \\
\hline Inequality $\ln (\mathrm{d} 5 / \mathrm{d} 1)$ & $\begin{array}{r}-.6073^{* * *} \\
(.0752)\end{array}$ & $\begin{array}{r}-.4457^{* * *} \\
(.0770)\end{array}$ & $\begin{array}{r}-.4542^{* * * *} \\
(.0736)\end{array}$ & $\begin{array}{r}-.4836^{* *} \\
(.2095)\end{array}$ & $\begin{array}{r}-.6912^{* * *} \\
(.1259)\end{array}$ \\
\hline Inequality $\ln (\mathrm{d} 9 / \mathrm{d} 5)$ & & & $\begin{array}{r}.1272 \\
(.1111)\end{array}$ & & \\
\hline Tertiary edu. $\ln (\mathrm{t} /(1-\mathrm{t}))$ & $\begin{array}{c}.0387^{*} \\
(.0199)\end{array}$ & $\begin{array}{r}.1041^{* * *} \\
(.0274)\end{array}$ & $\begin{array}{r}.1037^{* * *} * \\
(.0274)\end{array}$ & $\begin{array}{r}.0249 \\
(.0481)\end{array}$ & $\begin{array}{r}.0974^{* * *} \\
(.0263)\end{array}$ \\
\hline Union Density(pct) & $\begin{array}{r}.0026^{* * *} \\
(.0005)\end{array}$ & $\begin{array}{c}-.0009 \\
(.0009)\end{array}$ & $\begin{array}{l}-.0005 \\
(.0009)\end{array}$ & $\begin{array}{r}.0062^{* *} \\
(.0022)\end{array}$ & $\begin{array}{l}-.0002 \\
(.0008)\end{array}$ \\
\hline Openness (pct GDP) & $\begin{array}{r}.0058^{* * *} * \\
(.0005)\end{array}$ & $\begin{array}{l}-.0013 \\
(.0013)\end{array}$ & $\begin{array}{l}-.0012 \\
(.0013)\end{array}$ & $\begin{array}{l}-.0007 \\
(.0028)\end{array}$ & $\begin{array}{l}-.0018 \\
(.0013)\end{array}$ \\
\hline ln (GDP per cap.) & $\begin{array}{r}.3956^{* * *} \\
(.0806)\end{array}$ & $\begin{array}{r}.3894^{* * *} \\
(.0914)\end{array}$ & $\begin{array}{r}.3944^{* * *} \\
(.0922)\end{array}$ & $\begin{array}{r}.0637 \\
(.1946)\end{array}$ & $\begin{array}{r}.3434^{* * *} \\
(.0831)\end{array}$ \\
\hline Right cabinet $[0,1]$ & $\begin{array}{r}-.0748^{* * *} * \\
(.0193)\end{array}$ & $\begin{array}{r}-.0415^{* * *} \\
(.0103)\end{array}$ & $\begin{array}{r}-.0426^{* * *} \\
(.0103)\end{array}$ & $\begin{array}{l}-.0215 \\
(.0189)\end{array}$ & $\begin{array}{r}-.0323^{* *} \\
(.0103)\end{array}$ \\
\hline Share $65+$ (pct) & $\begin{array}{r}.0258^{* * *} * \\
(.0040)\end{array}$ & $\begin{array}{r}.0142^{* * *} \\
(.0036)\end{array}$ & $\begin{array}{r}.0145^{* * *} \\
(.0036)\end{array}$ & $\begin{array}{r}.0095 \\
(.0063)\end{array}$ & $\begin{array}{c}.0098^{* *} \\
(.0039)\end{array}$ \\
\hline Constant & $\begin{array}{r}-.9500 \\
(.7892)\end{array}$ & $\begin{array}{r}-.6661 \\
(.9239)\end{array}$ & $\begin{array}{r}-.8097 \\
(.9229)\end{array}$ & $\begin{array}{r}1.4765 \\
(1.9606)\end{array}$ & $\begin{array}{l}-.0264 \\
(.8568)\end{array}$ \\
\hline Country fixed eff. & & Y & $\mathrm{Y}$ & Y & Y \\
\hline p-value year dummies & .0000 & .0000 & .0000 & .9008 & .0000 \\
\hline p-value country dummies & & .0000 & .0000 & .0000 & .0000 \\
\hline F-first stage & & & & & 68.48 \\
\hline p-Sargan & & & & & .1728 \\
\hline p-WuHausman & & & & & .0238 \\
\hline No. of obs. & 344 & 344 & 344 & 344 & 344 \\
\hline
\end{tabular}

Dependent variable: $\ln$ (Overall Generosity Index) [Column 4: $\ln$ (Unemployment benefit generosity index).] Instruments for wage inequality in Column 5 are bargaining coordination and the share of workers in conflict. Unbalanced panel of 18 countries 1976-2002, see data section for details. All models include year dummies and controls for wage data source. Robust standard errors. 
Table 2: Fairness, Social Capital and Heterogeneity

\begin{tabular}{lrrrr}
\hline & \multicolumn{2}{c}{$\ln ($ Public Social Spending) } & Generosity \\
& Model 1 & Model 2 & Model 3 & Model 4 \\
\hline Inequality $\ln (\mathrm{d} 5 / \mathrm{d} 1)$ & & $-.5432^{* * *}$ & $-.4464^{* * *}$ & $-.4537^{* *}$ \\
& & $(.1420)$ & $(.1113)$ & $(.2158)$ \\
Luck vs Hard Work & $1.8872^{* * *}$ & $1.5173^{* * *}$ & $.8670^{* * *}$ & $.9932^{* *}$ \\
& $(.1505)$ & $(.1356)$ & $(.1998)$ & $(.3688)$ \\
Trust most people & $.5203^{* * *}$ & .1384 & .1001 & .4200 \\
& $(.1258)$ & $(.1118)$ & $(.1666)$ & $(.3327)$ \\
Immigrant percent & $-.0089^{* * *}$ & $-.0085^{* * *}$ & $-.0074^{* * *}$ & $-.0171^{* * *}$ \\
& $(.0019)$ & $(.0018)$ & $(.0019)$ & $(.0040)$ \\
Covariates & & & $\mathrm{Y}$ & $\mathrm{Y}$ \\
\hline Adjusted R sq & .78 & .83 & .95 & .84 \\
No. of obs. & 64 & 64 & 64 & 64 \\
\hline
\end{tabular}

Dependent variables: $\ln$ (Public Social Spending), [Overall Generosity Index in the last column]. Indicators for Luck versus Hard Work, and General Trust are wave and country specific averages from World Value Survey (see data section for details). Percent immigrants are obtained from OECD International data base. Years 1994-2002, 12 countries. The last 2 models include the same controls as in Table 1 (tertiary education, share of elderly, right wing government, union density, openness and ln GDP per capita). The models also include controls for $\ln$ (unemployment) and wage data source as in the full model (see data section for details) and year dummies. Robust standard errors.

wage inequality is instrumented by bargaining coordination and the share of workers who have participated in conflicts. ${ }^{14}$ Identifying variation is thus provided by changes in the bargaining regimes within these countries over this period. 10 countries have experienced a decentralization of bargaining during the sample period, 5 countries have seen no change while 3 countries have increased coordination. Workers in conflict has changed within every country where 14 countries have experienced more peaceful relations in the 2000's than in the late 1970's. The identifying variation is thus not based on a few observations only. We also show that the results are robust to the removal of a comprehensive set of sub-groups of countries. ${ }^{15}$ The IV estimator gives an elasticity of generosity with respect to wage inequality of -0.69 . The F-value from the first stage shows that we have strong instruments and the Sargan test suggests that they need not be included in the equation. The Wu-Hausman test indicates endogeneity of wage inequality, an observation in line with out theoretical framework, displaying feedback effects between welfare generosity and wage inequality.

\footnotetext{
${ }^{14}$ Bargaining coordination is measured as the average level of bargaining coordination over the last 10 years, using the coordination index obtained from the data base of Wallerstein and Golden. The share of workers in conflict is obtained from ILO. See data section for details.

${ }^{15}$ Robustness is further discussed below and in the appendix
} 


\section{Norms and beliefs}

Norms and beliefs also affect the political demand for welfare spending. For instance, welfare spending is higher in countries where voters attribute success in life to a larger degree to luck than to hard work (Piketty 1995, Alesina and Angelotes, 2005); where the level of trust in society is high (Putnam 1995, Rothstein, 2002); where voters are able to identify with welfare recipients, and where the ethnic composition of the population is not too heterogenous (Alesina and Glaeser, 2004).

As perceptions about luck versus hard work, social trust, and population heterogeneity may be correlated with wage inequality in various ways, we need to check if the negative correlation between welfare generosity and wage inequality is not simply due to such underlying norms and perceptions. To do this we add indicators of norms to our generosity equation. The indicators of luck and trust are taken from the World Value Survey, and averaged by wave and country. ${ }^{16}$ As an indicator of heterogeneity we use the share of immigrants in the population, taken from OECD statistics. Since the norm variables do not vary properly over time, we cannot use country fixed effects models, but have to rely on OLS models including countryXtime specific covariates and year dummies only. ${ }^{17} \mathrm{We}$ have been able to merge 64 observations from 12 countries from our sample to the World Value Survey. The results are shown in Table 2.

To be in line with the literature, we first show results using public social spending as our measure of welfare generosity. We find that public social spending is positively correlated with the perception that luck determines success, with general trust in other people, and negatively correlated with the share of immigrants in the economy, all in line with what previous literature would suggest. In Model 2, we add inequality. Inequality is significantly negative, with an elasticity of -.54 . The luck variable drops somewhat in magnitude, but is still highly significant, both economically and statistically, - the heterogeneity also remains significant. The trust variable disappears, and it seems that the positive coefficient observed in model 1 is due to a negative correlation between inequality and general trust in the society. Adding covariates reduces the coefficient somewhat (Model 3). Using the Overall Generosity Index in stead of public social spending (Model $4)$, we find very similar results.

The coefficient for wage inequality is large and significant, and clearly suggests that the negative equality magnifying effect observed in Table 1 is not due to a spurious correlation between norms, perceptions, or the heterogeneity of the population and wage inequality.

We should interpret these results with some caution; firstly, they are estimated without

\footnotetext{
${ }^{16}$ We merged the relevant waves of the World Value Survey to our data by wave, such that respondents who have answered to wave 2 are merged into data from 1994 to 1999, wave 3 from 2000 to 2004 and so on

${ }^{17}$ For the same reason we are unable to use coordination in bargaining as an instrument for wage inequality, since without country dummies it fails to satisfy the Sargan test, suggesting that there are country specific factors that are correlated with both coordination and generosity
} 
country fixed effects and could be spuriously correlated with other country attributes; secondly, some of the norms or perceptions may be endogenous. For instance, there is a literature suggesting that the welfare state may have a negative impact on social capital and general trust (see eg.Fukuyama, 2000). For our purpose, however, it is still comforting to note that our key result is robust to the inclusion of these norms. Our observed relationship between wage inequality and the generosity of the welfare state is not simply due to a positive correlation between norms and inequality, between general trust and inequality, or between the heterogeneity of the population and inequality. This result strengthens our interpretation of the negative coefficient of -.69 reported in Model 5 in Table 1 as a reflection of the equality magnifying effect.

\section{Wage Equalization}

According to the wage equalization effect, welfare generosity compresses wage dispersion because it tends to increase the relative bargaining power of low wage workers. Table 3 provides empirical estimates of this effect. Since the model predicts feedback effects, and we have already seen an effect of wage dispersion on generosity, we rely only on instrumental variable estimates. Instruments for welfare generosity are right wing government (average of last five years with more than 50 percent of the cabinet seats held by right wing party), and the share of the population over 65 years of age. There is considerable variation in right wing versus left wing governments within the countries of our sample. The period we cover includes the Regan/Thatcher eras, with subsequent follow ups in many countries, as well as periods of more left wing governments. All countries have experienced a growing share of elderly, however, both the speed and acceleration of this growth differs considerably. All in all there is ample variation in these variables within most of the countries of our study, and our results on wage equalization are also robust to the exclusion of sub-sets of countries. Further robustness tests are discussed below.

The first model shows the results without country fixed effects. The elasticity of wage dispersion with respect to generosity is estimated to -.43. We note that the overidentification test is not satisfactory, suggesting that the estimates are not robust to the choice of instruments. Model 2 includes fixed country effects. This is our preferred model. We find an elasticity of -.42 . Now the overidentifacation test is satisfactory, suggesting that one or more of the instruments are correlated with the country fixed effect rather than with the transitory residuals of the fixed country effects model specification. Several of the coefficients for the covariates change sign once we include country fixed effects, notably openness that switches from positive to negative. Bargaining coordination remains negative whereas the prevalence of conflict tends to increase wage dispersion. The next two columns are robustness checks; Model 3 uses public social expenditure as the measure of generosity, and Model 3 has $\ln (\mathrm{d} 9 / \mathrm{d} 1)$ as the explanatory variable; the instruments seem 
Table 3: Wage Inequality

\begin{tabular}{|c|c|c|c|c|}
\hline & \multicolumn{3}{|c|}{$\ln (\mathrm{d} 5 / \mathrm{d} 1)$} & \multirow{2}{*}{$\begin{array}{r}\ln (\mathrm{d} 9 / \mathrm{d} 5) \\
\text { Model } 4 \\
\end{array}$} \\
\hline & Model 1 & Model 2 & Model 3 & \\
\hline \multirow[t]{2}{*}{ Generosity } & $-.4250^{* * *}$ & $-.4173^{* * *}$ & & -.0863 \\
\hline & $(.0785)$ & $(.1165)$ & & $(.0979)$ \\
\hline \multirow[t]{2}{*}{$\ln ($ Publ.Soc.Exp (pct GDP)) } & & & $-.4668^{* * *}$ & \\
\hline & & & $(.0960)$ & \\
\hline \multirow[t]{2}{*}{ Tertiary edu. $\ln (\mathrm{t} /(1-\mathrm{t}))$} & -.0192 & .0048 & $-.0736^{* * *}$ & .0126 \\
\hline & $(.0171)$ & $(.0257)$ & $(.0208)$ & $(.0184)$ \\
\hline \multirow[t]{2}{*}{ Union Density (pct) } & $.0010^{*}$ & $.0027 * * *$ & $.0038 * * *$ & $-.0019 * *$ \\
\hline & $(.0005)$ & $(.0008)$ & $(.0010)$ & $(.0006)$ \\
\hline \multirow{2}{*}{ Openness (pct GDP) } & $.0031^{* * *}$ & $-.0016^{*}$ & $-.0059^{* * *}$ & -.0005 \\
\hline & $(.0005)$ & $(.0009)$ & $(.0015)$ & $(.0006)$ \\
\hline \multirow{2}{*}{$\ln ($ GDP per cap.) } & $.3799^{* * *}$ & .0186 & $-.3517^{* * *}$ & .0149 \\
\hline & $(.0495)$ & $(.0755)$ & $(.0715)$ & $(.0631)$ \\
\hline \multirow[t]{2}{*}{ Barg. Coordination } & $-.0613^{* * *}$ & $-.0298 * * *$ & $-.0400 * * *$ & $-.0190^{* *}$ \\
\hline & $(.0058)$ & $(.0091)$ & $(.0089)$ & $(.0063)$ \\
\hline \multirow[t]{2}{*}{ Conflict (pct) } & -.0001 & $.0020 * * *$ & $.0020^{* *}$ & $-.0012^{* *}$ \\
\hline & $(.0008)$ & $(.0005)$ & $(.0008)$ & $(.0004)$ \\
\hline \multirow[t]{2}{*}{ Unempl.rate (pct) } & & & $.0046^{*}$ & \\
\hline & & & $(.0025)$ & \\
\hline \multirow[t]{2}{*}{ Constant } & $-1.8427^{* * *}$ & $1.6685^{* *}$ & $5.7078^{* * *}$ & $.8982^{* *}$ \\
\hline & $(.3940)$ & $(.5362)$ & $(.7802)$ & $(.4198)$ \\
\hline Country fixed eff. & & Y & Y & Y \\
\hline p-value year dummies & .0000 & .0052 & .0000 & .7864 \\
\hline p-value country dummies & & .0000 & .0000 & .0000 \\
\hline F-first stage & 39.53 & 12.57 & 8.32 & 12.57 \\
\hline p-Sargan & .0021 & .1393 & .3276 & .5409 \\
\hline p-WuHausman & .0012 & .0309 & .0035 & .4651 \\
\hline No. of obs. & 344 & 344 & 299 & 344 \\
\hline
\end{tabular}

Dependent variable: $\ln (\mathrm{d} 5 / \mathrm{d} 1)[$ Column $4: \ln (\mathrm{d} 9 / \mathrm{d} 5)$. Instruments for generosity are right wing government, and the share of population 65+. Unbalanced panel of 18 countries 1976-2002, see data section for details. All models include year dummies and controls for wage data source. Robust standard errors. 
to work fine in both of these models as well. We find an equality magnifying effect of public spending, and that the effect of welfare generosity on $\ln (\mathrm{d} 9 / \mathrm{d} 5)$ is much smaller in magnitude than the effect of welfare generosity on $\ln (\mathrm{d} 5 / \mathrm{d} 1)$, and not significantly different from zero.

\section{The Size of the Multiplier}

We combine the two preferred IV models of Table 1 and 3 into a joint 3-SLS estimation of $\partial G / \partial I=\Phi^{\prime}$ and $\partial I / \partial G=\Psi^{\prime}$ and the multiplier $m=\frac{1}{1-\Phi^{\prime} \Psi^{\prime}}$. The full 3 SLS estimation results as well as the reduced form models are provided in table 8 in the appendix. The estimated wage equalization effect is -0.46 , the equality magnifying effect is -.69 , and we thus obtain an estimate of the equality multiplier as large as 1.47, significantly greater than 1 at 5 percent level of significance. The multiplier quantifies the sum of the feedbacks between the equations of welfare generosity and wage inequality, suggesting that the immediate effect of a shift in any variable is magnified by 47 percent through the feedback loops.

The reduced form coefficients of the instruments provide measures of the effect of the instrument after all feedbacks have been worked through, whereas the 3SLS estimates for the same instruments provide measures of the immediate effect of the variable, conditional on the other endogenous variable. Each instrument thus offers a possible estimator of the multiplier $m$ as the ratio between the reduced form estimates and the 3SLS estimate for the same variable. We find estimates ranging from 1.43 (using the conflict variable) to 1.85 (using right wing government). The multipliers calculated in this way do not differ very much from our 3SLS estimate, suggesting that the instruments are reasonable. Since 3SLS provides an optimal weighting scheme between the different estimates, our preferred estimate remains 1.47. Using this preferred estimate of the multiplier we discuss three counter-factual experiments in order to illustrate the size of the feedbacks.

Keeping a right wing government for five years reduces the overall generosity index directly by 2.5 percent. This would then increase wage inequality by 1.2 percent, which again reduces welfare generosity. The equality multiplier summarizes all the feedbacks, implying that the total effect of a right wing government adds up to a reduction in overall generosity by 3.7 percent. The total effect on wage inequality via lower generosity is a 2 percent increase. These effects are statistically significant, but not very large in magnitude.

A change from full coordination to full decentralization (a drop in the index by 4 levels) increases wage inequality by 9.4 percent. This would then reduce the demand for welfare generosity of 6.5 percent, which again feeds back to wage inequality. The end result, taking the equality multiplier into account, is an increase in wage inequality of 13.8 percent and a drop in welfare generosity by 9.6 percent. Since the bargaining system 
has no direct effect on welfare generosity, this effect mimics the effect of any exogenous change in wage inequality that would imply 9.4 percent higher inequality. Examples of such changes could be skill-biased technological change or changes in the direction of more performance-related pay within firms.

Rising GDP per capita by 10 percent has a direct effect on both generosity $(+3.4$ percent) and wage inequality ( +0.3 percent). The rise in generosity, however, changes the impact on wage inequality via the multiplier. Taking the feedbacks into account the overall effect is a 1.8 percent reduction in wage inequality accompanied with a 4.8 percent increase in generosity. Even inequitable economic growth can therefore produce more wage equality when adjustments via welfare spending are taken into account.

\section{Robustness}

A typical worry when using international data sets is that the results could be driven by the outcomes of a few countries, or by peculiar patterns of change in the instrumental variables. We have re-estimated the equations excluding different sets of countries, one group at the time. The estimates, reported in table 9 in the appendix, show that our key result do not depend on the inclusion of any groups of countries in our sample. As the table shows the equality magnifying effect and the wage equalizing effect are larger when the small and rather egalitarian countries are excluded (Small EU and Nordic), implying that the multiplier $m$ is highest in countries with relatively large initial inequalities. The estimated multiplier ranges from 1.28 to 2.03 depending on the countries excluded.

We have also estimated the model using OECD wage data only (excluding observations from the ECHP). The sample shrinks to 321 observations, but the results remain similar, with an estimated equality multiplier of 1.44 (see Table 10 in Appendix C).

Our sample is mainly limited by the availability of the overall generosity index; this is why our data stops already in 2002. We do have data on public social spending, however, from more countries and for more recent years. As a robustness test, we use public social spending to impute welfare generosity up through 2007 and for several OECD countries that are not included in the data set. Table 10 in the appendix also show results where the data is extended through 2007 where available, for the countries that are included in the comparative welfare data set. The last two columns show results where we have also included data for Korea, Hungary, Spain, and Portugal. The results are somewhat less precisely identified, which is not surprising since some of the generosity measures are imputed using social public spending, but otherwise the results remain very similar to the main model, displaying multipliers of 1.32 and 1.37 in the two extended samples.

Finally, we investigate the validity of our key instruments, bargaining coordination and right government, by using the 5 year lead of these variables in stead of their lags to construct the indicators. Constructed in this way, the indicators fail completely to 
predict the endogenous variables in the first stage ${ }^{18}$, providing support to the notion that our original instruments are exogenous.

\section{Persistence and long run effects}

Welfare generosity and the wage distribution change only slowly and that there seems to be a lot of persistence in both variables. Most of our exogenous variables, such as demographics and GDP change slowly as well, and there seems to be persistent variation across countries, or clusters of countries, in both politics and wage setting regimes. This creates two problems for our analysis. First, we lose a lot of variation when we use country fixed effects, utilizing only the 'transitory' variation in the exogenous variables. Second, we may miss out some underlying dynamics that may affect our estimates as well. In this section we use two methods (IV 3SLS with no country fixed effects, and system GMM with lagged endogenous variables) to investigate the potential impact of these issues for our conclusions.

\section{Excluding country fixed effects}

In order to sweep out heterogeneity across countries, the fixed effect models use only variation within all the countries over this 27 year period. However, cross country heterogeneity is of course also potentially due to the mechanisms we discuss in this paper. A long run representation of the model would make use of the long run variation as well, for instance estimated by standard cross sectional OLS. The reason why we do not use such a specification is that the models may be contaminated by a host of unobserved factors that may affect both the endogenous and the exogenous variables. An instrumental variable approach may alleviate this problem, and the first models of table 4 provide key results ${ }^{19}$ from the 3SLS specification of our two equations without country dummies.

Keeping in mind that this specification may be contaminated by the possible correlation between country-specific factors determining both the instruments and the endogenous variables, we still want to note three observations. The first is that the two key effects are only slightly weakened (-.66 vs. -.69 and -.43 vs. -.46), and overall the multiplier shrinks to 1.39 .

Second, without accounting for country fixed effects, the long run relationships between openness and both welfare generosity and wage inequality are positive. ${ }^{20}$ This observation is consistent with the view of a high level of openness being associated with higher risk, and thus a larger demand for social insurance, even though the short term impact of transitory changes in openness is negative (see Table 1 and eg. Rodrik, 1997).

\footnotetext{
${ }^{18}$ Results available on request.

${ }^{19}$ full results are reported in table 11 in Appendix C.

${ }^{20}$ See appendix table 11 for the full results including for the covariates
} 
Table 4: Welfare Generosity and Wage Inequality. Persistence and long run effects

\begin{tabular}{|c|c|c|c|c|}
\hline & \multicolumn{2}{|c|}{ IV-no country effects } & \multicolumn{2}{|c|}{ Blundel-Bond-GMM-sys } \\
\hline & $\begin{array}{r}\text { Generosity } \\
\text { Coef./se }\end{array}$ & $\begin{array}{l}\text { Inequality } \\
\text { Coef./se }\end{array}$ & $\begin{array}{r}\text { Generosity } \\
\text { Coef./se }\end{array}$ & $\begin{array}{r}\text { Inequality } \\
\text { Coef./se }\end{array}$ \\
\hline Inequality & $\begin{array}{r}-6637^{* * *} \\
(.0965)\end{array}$ & & $\begin{array}{r}-.0755^{*} \\
(.0387)\end{array}$ & \\
\hline Generosity & & $\begin{array}{r}-.4250^{* * * *} \\
(.0687)\end{array}$ & & $\begin{array}{r}-.0597^{* *} \\
(.0187)\end{array}$ \\
\hline L.Generosity & & & $\begin{array}{r}.9148^{* * * *} \\
(.0320)\end{array}$ & \\
\hline L.Inequality & & & & $\begin{array}{r}.8396^{* * *} \\
(.0381)\end{array}$ \\
\hline Estimated long run multiplier & 1.3 & & & \\
\hline Sargan p-value & $\begin{array}{r}.0000 \\
344\end{array}$ & $\begin{array}{r}.0000 \\
344\end{array}$ & $\begin{array}{r}.1751 \\
301\end{array}$ & $\begin{array}{r}.4563 \\
301\end{array}$ \\
\hline
\end{tabular}

Dependent variables: $\ln$ (Overall Generosity Index) and $\ln (\mathrm{d} 5 / \mathrm{d} 1)$.GMM sys specification: Lagged levels of generosity and inequality dated t-2 and earlier are used as instruments for the equations in first-differences; and (correspondingly) the lagged first-differences of generosity and inequality as instruments for the equations in levels. We include the exogenous variables as well as the instruments from Table 1 (bargaining coordination, right government and so on) as standard instruments in the equations. Year dummies are included as instruments in the levels equation only. IV without country effects: Instruments for wage inequality are bargaining coordination and workers in confict. Instruments for generosity are right cabinet and percent elderly $(65+)$ 
The positive relationship between openness and wage inequality may be consistent with the forces of factor price equalization working in the very long run, even if they do not appear to be particularly important in the short run.

Third, the effects of our instruments, in particular right government and bargaining coordination are much larger, in the order of 2-3 times larger, once we utilize variation between countries as well. The coefficient for bargaining coordination implies 25 percent lower wage inequality in a country with decentralized bargaining versus one with fully coordinated bargaining, adding up to a difference of 34 percent after taking the equality multiplier into account. Similarly, 5 years with right wing government implies 7 percent lower generosity, adding up to a difference of 10 percent after taking the equality multiplier into account.

\section{Lagged endogenous variables}

One way to incorporate persistence and long run effect is to estimate the model augmented with lagged endogenous variables. We estimate each equation separately, combining two representations of the same equation in a system consisting of both the first difference and the equation in levels (using system $\mathrm{GMM}^{21}$, see Blundell and Bond 2000). Both variables display high levels of persistence, with coefficients of the lagged endogenous variables of .91 and .84 respectively. Still, both coefficients are significantly different from one. ${ }^{22}$

We can solve for the long run (steady state) coefficients. ${ }^{23}$ This yields a long run effect on inequality of generosity of -.88 and a long run effect of generosity on inequality of -.37. Compared to the short term effects, it seems that the effect of generosity on inequality is enforced over time, whereas the effect of inequality on generosity is somewhat weakened. These coefficients suggest an equality multiplier of 1.49 in the long run, very close to the fixed effect estimates of Table 8.

Again we note that the effect of openness on generosity is positive (see appendix table A3), with a long run coefficient of 0.007 , which is quite close to what we obtain in the IVspecification without country fixed effects. The long run effect of bargaining coordination on wage inequality is estimated to -.11 whereas the effect of industrial conflict changes

\footnotetext{
${ }^{21}$ We use the standard specification where we use lagged levels of generosity and inequality dated t-2 and earlier as instruments for the equations in first-differences; and (correspondingly) the lagged first-differences of generosity and inequality as instruments for the equations in levels. We include the exogenous variables as well as the instruments from Table 1 (bargaining coordination, right government and so on) as standard instruments in the equations. Year dummies are included as instruments in the levels equation only.

${ }^{22}$ Both for Generosity and Inequality the hypothesis that all panels contain unit roots are rejected, using a Fisher type of augmented Dickey Fuller test with 3 lags and drift. The same is the case for the residuals from the reduced form OLS regressions reported in table A1. Results available on request.

${ }^{23}$ Considering the two equations separately, conditional on the other endogenous variable, i.e. when ignoring the feedbacks through the equality multiplier. A coefficient on the lagged generosity variable of .9148 , for instance, implies that the long run coefficients of the generosity equation equal the short run coefficients multiplied by $1 /(1-.9148)=11.7$. The estimated long run effect of inequality on generosity is thus -.88 .
} 
sign and is more difficult to interpret. The effect of right government on generosity is not statistically significant, but the point estimate suggest a long run effect of about -.09, which again is close to the long run effect estimated without country dummies.

\section{Caveats}

Both methods used in Table 4 have some caveats: The specification without fixed country effects may be affected by heterogeneity across countries, a problem that is clearly indicated by the Sargan tests in both equations. The models pass the overidentification test in the fixed country effects specification of tables 1 and 3, but fail without fixed effects, suggesting that the instruments in table 4 may pick up some country specific factors that should be in the models. A possible caveat of the system GMM method, is that it relies on the assumptions allowing lagged representations of the endogenous variables to be used as instruments (see Blundell and Bond, 2000 for details). The Sargan tests, however, are satisfactory in both equations.

The results suggest that there is high persistence in both wage inequality and in welfare generosity and that the short run responses are smaller than the long run response. The results also indicate that the fixed country effects models of Table 1 rather underestimate the effect of inequality on generosity compared to the long run effect, but that the effect of generosity on inequality may be attenuated rather than enforced in the longer run. The long run equality multiplier seems to be quite similar to the ones estimated in the 3SLS specification. Furthermore, the results suggest that the effects of our key instruments, bargaining coordination and right government, are conservatively estimated in the 3SLS specification.

Because of the caveats associated with the specifications in table 4 we keep the 3SLS model as our preferred specification.

\section{Exploiting an alternative time series for the US 1945-2001}

Our last attempt to quantify the magnitude of the equality multiplier uses single time series over 57 years in the US. We use data from 1945 to 2001, drawn from different sources than what is used in the previous analysis. ${ }^{24}$

Table 5 shows key results from two different IV-specifications. ${ }^{25}$ For reasons of compar-

\footnotetext{
${ }^{24}$ The reason is that we need observations from the time period 1945-1975 in addition to what we have used so far. Using separate sources also add an element of robustness check to our analysis of course. Welfare generosity is represented by social spending in percent of GDP. The data are taken from Historical Statistics of the US, and the programs include social insurance, public aid, health and medical programs, veteran programs, housing and other social welfare programs. The wage inequality data is the series of the d9-d1 ratio of male hourly wages reported in Goldin and Katz (2007). The series underlying Figure 5 in Goldin and Katz (2007) is kindly provided by the authors. Details are reported in the data appendix.

${ }^{25}$ Table 12 in Appendix $\mathrm{C}$ provides the full regression results. A Dickey Fuller test reject a unit root in both endogenous variables, DF p-values: Social spending 0.0037, Wage inequality 0.0320 with trend.
} 
Table 5: Generosity and Wage Inequality, United States 1945-2001

\begin{tabular}{lrrrr}
\hline & $\begin{array}{r}\text { Social Spending } \\
\text { Coef./se }\end{array}$ & $\begin{array}{r}\text { Inequality } \\
\text { Coef./se }\end{array}$ & $\begin{array}{r}\text { Social Spending } \\
\text { Coef./se }\end{array}$ & $\begin{array}{r}\text { Inequality } \\
\text { Coef./se }\end{array}$ \\
\hline Inequality & $\begin{array}{r}-1.5119^{* *} \\
(.6055)\end{array}$ & & $\begin{array}{r}-1.0637^{* * *} \\
(.2665)\end{array}$ & \\
$\ln$ (Soc. Spending) & & $-.1570^{* * *}$ & & $-.1623^{* * *}$ \\
& & $(.0397)$ & & $(.0387)$ \\
\hline Equality mult. & 1.31 & & 1.21 & \\
Hansen J, p-value & .4834 & .1247 & .2917 & .1603 \\
Cragg-Donald F & 5.44 & 16.66 & 36.89 & 17.84 \\
No. of cases & 57 & 57 & 57 & 57 \\
\hline
\end{tabular}

Dependent variables: $\ln$ (Social Spending pct gdp) and $\ln (\mathrm{d} 9 / \mathrm{d} 1)$ gross wages. Instruments for wage inequality included in the first model are bargaining coordination and the share of workers in conflict, the next model use union density as an instrument in stead of workers in conflict. Instruments for generosity included in the IV specifications are dummies for the republican presidential periods: Eisenhower, Nixon-Ford and Regan-Bush, and the share of elderly $(65+)$. Statistics from 2SLS robust to heteroscedasticity and autocorrelation. See table 12 for full results.

ison the first models use the same instruments as in the panel data analysis: bargaining coordination $^{26}$, workers in conflict, right wing government with a separate dummy for each republican period Eisenhower, Nixon/Ford and Reagan/Bush, and the percentage elderly in the population $(65+)$. We note that the instruments for wage inequality do not have a very strong bite in the first stage (F-value of 5.44), and in the second set of models, workers workers in conflict is replaced by union density as an instrument. Since this is time series data from one country only, year dummies and slow moving variables as $\ln$ gdp per capita and openness are replaced by a single trend variable only. ${ }^{27} \mathrm{We}$ find clear support for both the equality magnifying effect (higher wage dispersion reduces welfare spending) and the wage equalizing effect (higher welfare spending reduces wage dispersion). The estimated equality multipliers are 1.21 and 1.31.

There is a strong underlying positive trend towards higher social spending in the US, most likely from an increased demand for social insurance among voters as GDP per capita grows. We also find that the increase in wage inequality after 1975 and in particular from the 1980's onwards ${ }^{28}$ would have led to a retrenchment of social spending. One interpretation of this, in line with our model, is that rising wage inequality after 1980 (partly due to technological change and partly due to changes in unionism) lead to a drop

\footnotetext{
${ }^{26}$ Bargaining coordination is provided in the data from 1960 on, based on observations of bargaining coordination from 1950 onwards in the Wallerstein/Golden data set. For the earlier years, bargaining coordination and workers in conflict are imputed using union density and trend.

${ }^{27}$ The results are very similar if we in the first set of models replace the trend by $\ln g d p$ per capita. In that case, the estimated elasticity of generosity with respect to gdp per capta is about 1 . Including both $\ln$ gdp per capita and a trend gives a negative, insignificant coefficient for $\ln g d p$ per cap.

${ }^{28}$ See for instance Katz and Autor, 2005.
} 
in income for the median worker relative to the overall trend. This relative deprivation reduced the popular demand for social insurance making it easier for president Ronald Reagan to get closer to his preferred level of welfare generosity without loosing voters, while the Democrats had to move in the same direction in order not to lose voters.

However, the surge in wage inequality during the 1980's was considerably steeper as a result of an independent retrenchment of social spending in addition to the endogenous response in spending. All in all this added to inequality growth in the labor market. One interpretation of this development, which would be in accordance with our model, is that the underlying increase in wage inequality was kept in check as a result of increased relative bargaining power of low wage groups from the expansion of social insurance from the 1960's onwards. The retrenchment period of the 1980's on, however, reduced the relative bargaining power of low wage groups which allowed wage inequality to surge even more than the underlying trend.

One should exercise caution when interpreting the results from a single time series, and we do not regard the evidence presented in this section as sufficient casual evidence by itself for the mechanisms we propose. The results, however, do fit nicely with the more robust results from the panel study across countries and thus provide additional empirical support for our propositions.

\section{Conclusion}

Why does a high level of pre tax inequality favor a small rather than a large welfare state? The basis for our answer in this paper is that higher inequality means lower incomes relative to the mean for a majority of voters. With a lower income each of them would like to allocate a larger share of it to immediate consumption rather than to tax-financed welfare programs with less direct benefits. Thus, increasing wage inequality means a declining electoral support for a larger welfare state, and an increasing electoral support for a smaller one.

Faced with voters with more unequal incomes, proponents of the welfare state (political parties or blocks) have to run on a less ambitious welfare program in order not to lose voters, while proponents of a smaller welfare state can satisfy more of their ideological preference for welfare cuts without losing as many voters as otherwise. As a result the political equilibrium change in the direction of less generous welfare spending. Conversely, a more equal distribution of incomes means that the political equilibrium changes in the direction of a more generous welfare spending. Thus smaller wage differentials induce larger welfare states - what we denote the equality magnifying effect.

Why does not a tax financed welfare state favor increasing rather than decreasing wage differentials? Our simple answer is that generous welfare programmes first and foremost increase the bargaining power of weak groups in the labor market. Thus larger welfare 
states induce smaller wage differentials - what we denote the wage equalization effect.

We have shown how these two effects, the wage equalization effect and the equality magnifying effect, together generate a self-enforcing process that adds up to a sizable social multiplier. Along the development path economic and social equality can multiply due to the complementarity between politics and markets. Accordingly, higher equality may induce even more equality; and higher inequality may induce more inequality. In both cases we obtain a pattern where welfare generosity and wage inequality become negatively related. The simultaneity problem inherent in our theoretical model makes it difficult empirically to obtain a identification of the two separate effects, and our results should thus be interpreted with appropriate caution. Using an instrumental variable approach we find a sizeable inequality multiplier of around 1.5 in our preferred specifications. This means that an initial impulse that affects either welfare generosity, wage equality, or both, has a 50 percent stronger effect on the same variable after the feedback between the two has been allowed to work. There appears to be rather high persistence in both variables, suggesting that the feedbacks take time to work.

Our results do not apply to European style welfare states only. Also within the US the feedback effects have a strong impact on the joint development of social spending and wage inequality. This is further explored using US time series data from 1945 to 2002, providing additional empirical support for our mechanisms. There are trends in the US data caused by GDP growth, new technologies and institutional change. Up until the late 1960's, the growth in social spending tends to strengthen the forces underlying the 'great compression' of wages. In this period social spending seems to keep the growth in wage inequality in check, sustaining the growth in welfare spending. After the late 1970's, however, US experiences a retrenchment in social spending strengthening the underlying forces of increasing wage inequality.

While the trends in the US, at least since 1980, have been towards greater economic and social inequality, the trends both in the labor market and in social policies have been less distinct in European welfare states. The social multiplier enhances long term consequences of these underlying trends. In this way the equality multiplier magnifies differences across countries over time and may help explaining for instance why the Scandinavian countries have twice as generous welfare spending as the US, and only half of its pre-tax wage inequality. 


\section{References}

Acemoglu, Daron (2003), 'Cross-country inequality trends', Economic Journal, 113 (485), 121-49

Alesina, Alberto and George-Marios Angeletos (2005). "Fairness and Redistribution: US vs. Europe," American Economic Review, September, 95: 913-35.

Alesina, Alberto, Guido Cozzi and Noemi Mantovan (2009), the evolution of ideology, fariness, and redistribution, WP 15587, NBER.

Alesina, Alberto, Edward Glaeser, and Bruce Sacerdote, (2001) "Why Doesn't The US Have a European-Style Welfare State?," Harvard Institute of Economic Research Working Papers 1933, Harvard - Institute of Economic Research.

Alesina, Alberto, and Edward Glaeser (2004) Fighting Poverty in the US and Europe: A World of Difference, Oxford: Oxford University Press.

Armingeon, Klaus, Philipp Leimgruber, Michelle Beyeler, and Sarah Menegale, (2007) Comparative Political Data Set 1960-2004 update (2007-03$01)$.

Autor, D.H., L.F. Katz and M. Kearney (2008), 'Trends in U.S. wage inequality: revising the revisionists', Review of Economics and Statistics.MIT Press, vol. 90(2), pages 300-323.

Baldwin, Peter (1990) The Politics of Social Solidarity: Class Bases of the European Welfare State, 1875-1975, Cambridge University Press, Cambridge.

Barr, Nicholas (1992) "Economic Theory and the Welfare State: A Survey and Interpretation" Journal of Economic Literaturevol. 30:741-803.

Barth, Erling, Alex Bryson, James C. Davis, and Richard Freeman (2010) "The Contribution of Dispersion across Plants to the Increase in the US Earnings Dispersion" Paper presented at the 2010 NBER Summer Institute, Cambridge MA.

Benabou, Roland (2000) "Unequal Societies: Income Distribution and the Social Contract" American Economic Review, vol. 90(1), pages 96-129.

Blau, Francine D and Lawrence M. Kahn (1996) "International Differences in male wage inequality: institutions versus market forces" Journal of Political Economy Vol 104:791-837. 
Blundell, Richard and Stephen Bond, 2000. "GMM Estimation with persistent panel data: an application to production functions," Econometric Reviews, Vol. 19(3):321-340.

Bowles, Samuel and Herbert Gintis, (1993) "The revenge of Homo Economicus: Contested exchange and the revival of political economy." Journal of Economic Perspectives, 7;1, 83-102.

Bratsberg, Bernt, Elisabeth Fevang and Knut Røed (2010) "Disability in the Welfare State: An Unemployment Problem in Disguise?" IZA Discussion paper No 4897

Browning, Robert X. (1986) Politics and Social Welfare Policy in the United States. Knoxville, TN:University of Tennessee Press.

Cameron, David R. (1978) "The Expansion of the Public Economy: A Comparative Analysis" American Political Science Review vol. 72(4):12431261.

Card, David (2001) "The Effects of Unions on Wage Inequality in the U.S. Labor Market" Industrial and Labor Relations Review, 54(2):296-315.

Card, David and John E. DiNardo (2002) "Skill-Biased Technological Change and Rising Wage Inequality Some Problems and Puzzles" Journal of Labor Economics, Vol 20(4):733-783.

Devroye, Dan and Richard Freeman (2001) "Does inequality in skills explain inequality of earnings across advanced countries? NBER Working paper 8140 .

DiNardo, John, Nicole M Fortin, and Thomas Lemieux (1996) "Labor Market Institutions and the Distribution of Wages, 1973-1992: A Semiparametric Approach," Econometrica, vol. 64(5), pages 1001-44, September.

Di Tella, Rafael and Juan Dubra (2010), A note on Fairness and Redistribution, Harvard Business School, Working Paper, 11-059.

Ebbinghaus B. and J. Visser (2000), Trade unions in western Europe since 1945, Macmillan.

Esbing-Andersen, Gösta (1990) Three Worlds of Welfare Capitalism Princeton, NJ:Princeton University Press.

Farber, Henry S. (2011) "Job Loss in the Great Recession: Historical Perspective from the Displaced Workers Survey, 1984-2010" Working paper No. 564 Industrial Relations Section, Princeton University

Freeman, Richard B. (1991) "How Much Has De-Unionisation Contributed to the Rise in Male Earnings Inequality?," NBER Working Papers 3826, 
National Bureau of Economic Research, Inc.

Fuente de la, Angel and Rafael Domenech (2006) "Human Capital in Growth Regressions: How Much Difference Does Data Quality Make?," Journal of the European Economic Association vol. 4(1):1-36.

Fukuyama, Francis (2000), Social Capital and Civil Society, IMF Working Paper WP/00/74, International Monetary Fund.

Gibbons, R. and L. Katz (1992) "Does Unmeasured Ability Explain Interindustry Wage Differentials?", Review of Economic Studies, 59:515-535.

Glaeser, Edward, B. Sacerdote and J Scheinkman (2003) "The Social Multiplier" Journal of the European Economic Association 1(2):345-353.

Golden, Miriam; Peter Lange; and Michael Wallerstein (2006) "Union Centralization among Advanced Industrial Societies: An Empirical Study." Dataset available at http://www.shelley.polisci.ucla.edu/

Goldin, Claudia and Robert A. Margo (1992) "The Great Compression: The Wage Structure in the United States at Mid-century," The Quarterly Journal of Economics, vol. 107(1):1-34.

Goldin, Claudia and Lawrence F. Katz (2007) "Long-Run Changes in the Wage Structure: Narowing, Widening, Polarizing" Brookings Papers on Economic Activity, 2:2007.

Goldin, Claudia and Lawrence F. Katz (2008) "The Race between Education and Technology: The Evolution of U.S. Educational Wage Differentials, 1890 to 2005" Chapter 8 of Goldin and Katz, The Race between Education and Technology, Harvard University Press.

Groschen, Erica (1991) "Sources of Intra-Industry Wage Dispersion: How Much Do Employers Matter?" Quarterly Journal of Economics, vol. 106.

Heston, Alan, Robert Summers and Bettina Aten (2006) Penn World Table Version 6.2, Center for International Comparisons of Production, Income and Prices at the University of Pennsylvania, September 2006.

Historical Statistics of the United States, Millennial edition, US Department of Commerce.

Holmlund, Bertil and Lundborg, Per (1999) "Wage bargaining, union membership, and the organization of unemployment insurance," Labour Economics, Elsevier, vol. 6(3):397-415.

Huber, Evelyne, Charles Ragin, John D. Stephens, David Brady, and Jason Beckfield (2004) Comparative Welfare States Data Set, Northwestern University. 
Iversen, Torben and David Soskice (2001) "An Asset Theory of Social Policy Preferences", American Political Science Review vol. 95(4):875-893.

Kahn, Lawrence (2000) "Wage Inequality, Collective Bargaining and Relative Employment 1985-94: Evidence from 15 OECD Countries"; The Review of Economics and Statistics 82:(4).

Katz, Lawrence F, and David H. Autor (1999) "Changes in the Wage Structure and Earnings Inequality" in Ashenfelter and Card: Handbook of labor economics 3A. Amsterdam: Elsevier Science, North Holland.

Katz, Lawrence F, and David H. Autor (2005)

Katz, Lawrence F and Kevin M. Murphy (1992) "Changes in Relative Wages, 1963-87: Supply and Demand Factors" Quarterly Journal of Economics Vol. 107:35-87.

Katzenstein, Peter (1985) Small States in World Markets: Industrial Policies in Europe Cornell University Press.

Krueger, A.B. and L.J. Summers (1988) "Efficiency Wages and the Interindustry Wage Structure", Econometrica, 56:259-293.

Lee, Woojin and John E. Roemer, (2006) "Racism and redistribution in the United States: A solution to the problem of American exceptionalism" Journal of Public Economics, 90, 1027-1052

Leuven, E., H. Oosterbeek and H. van Ophem (2004), 'Explaining international differences in male skill wage differentials by differences in demand and supply of skill', Economic Journal, 114 (495), 466-86.

Levy, Frank and Richard J Murnane (1992) "U.S. Earnings Levels and Earnings Inequality: A Review of Recent Trends and Proposed Explanations," Journal of Economic Literature, American Economic Association, vol. 30(3), pages 1333-81, September.

Lind, Jo Thori (2005) "Why is there so little redistribution?" Nordic Journal of Political Economy 31: 111-125.

Lindert, Peter H. (2004) Growing Public: Social Spending and Economic Growth since the Eighteenth Century Cambridge University Press.

Lindert-Allard Data set. (2008) http://www.econ.ucdavis.edu/faculty/ fzlinder/OECD $\backslash \% 20$ data.htm

Meltzer, Allan H. and Scott F. Richard (1981) "A Rational Theory of the Size of Government" Journal of Political Economy vol.89:914-27. 
Milanovic, Branko, 2000. "The median-voter hypothesis, income inequality, and income redistribution: an empirical test with the required data," European Journal of Political Economy, Elsevier, vol. 16(3), pages 367-410, September.

Moene, Karl Ove and Michael Wallerstein (1997) "Pay Inequality" Journal of Labor Economics, vol.15:403-430

Moene, Karl Ove and Michael Wallerstein (2001) "Inequality, Social Insurance, and Redistribution" American Political Science Review vol. 95(4):859-874.

Moene, Karl Ove and Michael Wallerstein (2003), "Earnings Inequality and Welfare Spending: A Disaggregated Analysis" World Politics vol.55(4):485516.

Moffitt, Robert, David Ribar, and Mark Wilhelm (1998), "The decline of welfare benefits in the U.S.: the role of wage inequality." Journal of Public Economics, Elsevier, vol. 68(3), pages 421-452, June.

Osborne Martin J. and Ariel Rubinstein (1990), Bargaining and markets, Academic Press,

OECD (2007)

OECD (2011) Education at a Glance 2011. Paris: OECD

Perotti, Roberto (1993) "Political equilibrium, income distribution and growth." Review of Economic Studies 60, 755-776.

Perotti, Roberto (1996) "Growth, income distribution and democracy: What the data say." Journal of Economic Growth 1, 149-188.

Persson, Torsten and Guido Tabellini (2000) Political Economics, Explaining Economic Policy, the MIT Press, Cambridge.

Piketty, Thomas (1995) "Social mobility and redistribution politics", Quarterly Journal of Economics, 110, 551-584.

Pissarides, Christopher A. (2000), Equilibrium Unemployment Theory. The MIT Press, Cambridge.

Putnam, Robert David (1995) "Bowling Alone: America's declining social capital. Journal of Democracy, 1, 65-78.

Ramcharan, Rodney (2010) "Inequality and redistribution: Evidence from U.S. counties and states, 1890-1930," Review of Economics and Statistics, 92, 729-744.

Rodrik, Dani (1997) "Trade, Social Insurance, and the Limits to Globalization", NBER Working Paper No 5905, Cambridge: MA. 
Roberts, Kevis W.S (1977) "Voting over Income Tax Schedules" Journal of Public Economics vol.8:329-40.

Roemer, John (2001) Political Competition: Theory and Applications Cambridge,MA: Harvard University Press.

Romer, Thomas (1975) "Individual Welfare, Majority Voting, and the Properties of a Linear Income Tax" Journal of Public Economics vol.14:163-85

Rothstein Bo (2002), "Social capital in the democratic state", in R.D. Putnam (ed) Democracies in Flux, Oxford University Press.

Scheve, Kenneth and David Stasavage (2008) "Partisanship, and Inequality in the Long Run", Mimeo, New York University, June 2008.

Scruggs, Lyle (2004), Research on Globalization and the Welfare State: Do We Know What We Think We Know? Presented at a conference on Globalization and Equity at Duke University, May.

Scruggs, Lyle (2007) "Welfare State Decommodification in Time and Space" in Nico Siegal and Jochen Classen, eds. Welfare Reform in Advanced Societies: the Dependent Variable Problem in Comparative Welfare State Analysis. Edward Elgar 2007.

Therborn, Göran (1986), Why some people are more unemployed than others? London, Verso.

Tocqueville, Alexis de (1835) Democracy in America, University of Chicago Press, Chicago, 2000.

Wallerstein, Michael (1999) "Wage Setting Institutions and Pay Inequality in Advanced Industrial Societies" American Journal of Political Science, Vol.43:649-80. 


\section{Appendix A: Proof of proposition 2}

We first prove that each political party runs on a more pro welfare program the more compressed the wage structure for a given policy of the opposing party. Consider the first order condition for the the left party

$$
P_{L}^{\prime} \equiv \frac{\partial q\left(G_{L}, G_{R}\right)}{\partial G_{L}}\left[W_{L}\left(G_{L}\right)-W_{L}\left(G_{R}\right)\right]+q\left(G_{L}, G_{R}\right) \frac{\partial W_{L}}{\partial G_{L}}=0
$$

Clearly, $P_{L}^{\prime \prime}<0$ from the second order condition.

A mean preserving spread in the distribution of wages affects $G_{L}$ via its impact on $q$ and $q_{L}$ which from (13) can be written as $q=1 / 2+z f E_{w}\left[V\left(G_{L}: w\right)-V\left(G_{R} ; w\right)\right]$ and $q_{L}=z f E_{w}\left[V^{\prime}\left(G_{L}: w\right)\right.$. Both $\left[V\left(G_{L} ; w\right)-V\left(G_{R} ; w\right)\right]$ and $V^{\prime}\left(G_{L} ; w\right)$ are concave functions of $w$ as

$$
\begin{array}{r}
\operatorname{sign}\left[\frac{d^{2}\left[V\left(G_{L} ; w\right)-V\left(G_{R} ; w\right)\right]}{d w^{2}}\right]=\operatorname{sign}[ \\
\left.\left[U^{\prime \prime}\left(\left(1-t_{L}\right) w\right)\left(1-t_{L}\right)^{2}-U^{\prime \prime}\left(1-t_{R}\right) W\right)\left(1-t_{R}\right)^{2}\right] \\
=\operatorname{sign}\left[w^{-(\mu+1)} \mu\left(\left(1-t_{R}\right)^{1-\mu}-\left(1-t_{L}\right)^{1-\mu}\right)\right]<0
\end{array}
$$

and

$$
\left.\operatorname{sign} \frac{d^{2} V^{\prime}\left(G_{L}: w\right)}{d w^{2}}=\operatorname{sign}(\mu-1)\right) U^{\prime \prime}\left(\left(1-t_{L}\right) w\right)<0
$$

Accordingly, letting higher inequality $I$ be mean-preserving, we have from Jensen's inequality that $d q / d I<0$ and $d q_{L} / d I<0$. Using this in the first order condition for $G_{L}$ we obtain

$$
\frac{d G_{L}}{d I}=\frac{\left[W_{L}\left(G_{L}\right)-W_{L}\left(G_{R}\right)\right] d q_{L} / d I+W_{L}^{\prime}\left(G_{L}\right) d q / d I}{-P_{L}^{\prime \prime}}<0
$$

demonstrating that higher wage inequality leads the left party to moderate its welfare policy.

Similarly, we now consider the right party. The first order condition (4) for the determination of $G_{R}$ is

$$
P_{R}^{\prime} \equiv-\frac{\partial q\left(G_{L}, G_{R}\right)}{\partial G_{R}}\left[W_{R}\left(G_{R}\right)-W_{R}\left(G_{L}\right)\right]+\left(1-q\left(G_{L}, G_{R}\right)\right) \frac{\partial W_{R}}{\partial G_{R}}=0
$$

where the second order condition implies $P_{R}^{\prime \prime}<0$. A mean preserving increase in wage equality affects $G_{R}$ via $q$ and $q_{R}$. From (13 we have $-q_{R}=z f E_{w}\left[V^{\prime}\left(G_{R} ; w\right)\right.$. We can show that $V\left(G_{R} ; w\right)$ is concave in $w$ since

$$
\left.\operatorname{sign} \frac{d^{2} V^{\prime}\left(G_{R}: w\right)}{d w^{2}}=\operatorname{sign}(\mu-1)\right) U^{\prime \prime}\left(\left(1-t_{R}\right) w\right)<0
$$


Hence, using Jensen's inequality we have $d\left(-q_{R} / d I\right)<0$. From the first order condition for $G_{R}$ we have

$$
\frac{d G_{R}}{d I}=\frac{-\left(d q_{R} / d I\right)\left[W_{R}\left(G_{R}\right)-W_{R}\left(G_{L}\right)\right]-(d q / d I) W_{R}^{\prime}\left(G_{R}\right)}{-P_{L}^{\prime \prime}}<0
$$

(where $W_{R}^{\prime}\left(G_{R}\right)<0$ ) demonstrating that higher wage inequality also leads the right party to moderate its welfare policy.

Now, since both parties moderate their proposed policies, for any given policy of the opposing party where $G_{L}>G_{R}$, the new equilibrium after the mean preserving spread in the wage distribution must be one where both both parties propose a lower levels of generosity. It is straight forward to see that lower generosity implies higher wage dispersion. 


\section{Appendix B: Data sources and definitions}

The data used in the core analysis of this paper is a panel of 344 observations from 18 OECD countries from 1976 to 2002. Wage dispersion is measured by the ratio of the 5th to

the 1st decile of hourly gross wages, mainly provided by the OECD. Most of the OECD wage data are collected from the OECD Earnings database [http://www.oecd.org/ dataoecd/9/59/39606921.xls, http://stats . oecd.org/Index . aspx?DataSetCode=DEC-I], supplemented by data from Employment Outlook, 1996, Table 3.1 (1979-1995). Additional series are calculated on the European Community Household Survey- ECHP (1994-2001). In order to minimize measurement errors, an average over these sources is constructed for each countryxyear cell, so that each countryxyear is one observation. In the empirical analysis below, we always include a variable indicating the weight of the different sources (OECD, ECHP) in the construction of each countryxyear-cell average in order to account for potential heterogeneity in definitions etc. between the sources. Because of a large discrepancy in the Austrian OECD and ECHP series a separate indicator is included. In addition an indicator variable taking the value of 1 if wages are measured annually is included in all regressions involving wage dispersion. France, Italy, and Switzerland report net wages, but this is controlled for by the use of country dummies. Table 6 below provides an overview of the years covered from the different sources and a description of the ratio between the 5th decile and the first decile of pre-tax wages of the OECD countries from 1976 to 2005.

Generosity of the welfare state is measured by the overall generosity index provided in the Comparative Welfare Entitlements Dataset, constructed and generously made available for other researchers by Lyle Scruggs at the University of Connecticut. The index captures the generosity of income support in the case of illness, of unemployment and of disability pensions (including old age) of each country year cell. Generosity is constructed using both the replacement ratio, coverage, entitlements and timing of different schemes, in addition to other features of the schemes. The construction of the index is described in Scruggs (2004, 2007). The data set is available at http://sp.uconn.edu/symbol\{126\}scruggs/wp.htm).

Figure 5 displays the trend in the overall generosity index for each country in our sample, together with public social spending as reported by OECD.

The political variables used in our analysis are obtained from Armingeon et. al. (2007) Comparative Political Data Set (CPD). Right government is the five year average of an (current and lagged) indicator variable taking the value of one if the right parties has a majority in government (g.t. 50 percent), constructed from the variable govright (defined as right-wing parties in percentage of total cabinet posts, weighted by days) from (CPD) Armingeon et al (2007). The percent of elderly in the population is taken from the same 
Table 6: Wage ratio: d5/d1. 5 year averages

\begin{tabular}{|c|c|c|c|c|c|c|c|c|}
\hline Country & Dataset & & $1976-80$ & $1981-85$ & $1986-90$ & $1991-95$ & 1996-00 & 2001-05 \\
\hline Australia & OECD & & 1.62 & 1.68 & 1.68 & 1.64 & 1.63 & 1.66 \\
\hline \multirow[t]{2}{*}{ Austria } & OECD & $a, b, c$ & 1.94 & & 1.95 & 1.99 & & 1.70 \\
\hline & ECHP & & & & & 1.66 & 1.54 & 1.50 \\
\hline \multirow[t]{2}{*}{ Belgium } & OECD & & & 1.46 & 1.45 & 1.44 & 1.40 & 1.39 \\
\hline & ECHP & & & & & 1.56 & 1.52 & 1.56 \\
\hline Canada & OECD & $\mathrm{b}$ & & 2.24 & & 2.24 & 2.40 & 2.26 \\
\hline \multirow[t]{2}{*}{ Denmark } & OECD & & 1.41 & 1.40 & 1.40 & & 1.47 & 1.52 \\
\hline & ECHP & & & & & 1.39 & 1.38 & 1.45 \\
\hline \multirow{2}{*}{ Finland } & OECD & $\mathrm{b}$ & 1.53 & 1.48 & 1.47 & 1.41 & 1.40 & 1.42 \\
\hline & ECHP & & & & & & 1.48 & 1.49 \\
\hline \multirow[t]{2}{*}{ France } & OECD & $b, d$ & 1.79 & 1.69 & 1.63 & 1.63 & 1.62 & 1.58 \\
\hline & ECHP & & & & & 1.63 & 1.66 & 1.68 \\
\hline Germany & OECD & $\mathrm{c}$ & & 1.68 & 1.65 & 1.60 & 1.61 & 1.76 \\
\hline \multirow[t]{2}{*}{ Ireland } & OECD & & & & & 2.06 & 1.82 & 1.83 \\
\hline & ECHP & & & & & 2.07 & 1.90 & 1.69 \\
\hline \multirow{2}{*}{ Italy } & OECD & $\mathrm{a}, \mathrm{c}, \mathrm{d}$ & 1.89 & 1.72 & 1.43 & 1.41 & 1.38 & \\
\hline & ECHP & & & & & 1.50 & 1.49 & 1.51 \\
\hline Japan & OECD & $\mathrm{c}$ & 1.69 & 1.72 & 1.71 & 1.64 & 1.62 & 1.63 \\
\hline \multirow[t]{2}{*}{ Netherlands } & OECD & $\mathrm{b}$ & 1.59 & 1.54 & 1.56 & 1.57 & 1.65 & 1.65 \\
\hline & ECHP & & & & & 1.55 & 1.61 & 1.78 \\
\hline New Zealand & OECD & & & 1.48 & 1.51 & 1.52 & 1.59 & 1.56 \\
\hline Norway & OECD & $\mathrm{a}, \mathrm{c}$ & 1.41 & 1.37 & 1.45 & 1.32 & 1.38 & 1.43 \\
\hline Sweden & OECD & $\mathrm{b}$ & 1.39 & 1.31 & 1.31 & 1.33 & 1.36 & 1.38 \\
\hline Switzerland & OECD & $c, d$ & & & & & 1.50 & 1.47 \\
\hline UK & OECD & & 1.92 & 1.75 & 1.76 & 1.82 & 1.82 & 1.81 \\
\hline USA & OECD & & 1.90 & 1.94 & 1.98 & 2.04 & 2.08 & 2.07 \\
\hline OECD avg. & OECD & & 1.67 & 1.63 & 1.59 & 1.67 & 1.63 & 1.65 \\
\hline
\end{tabular}

Source: 5-years averages of available years from OECD Earnings database, ECHP European Community Household Panel. a) data from 1976-95 is supplemented from Employment Outlook 1996, table 3, b) Annual earnings, (Austria 04-05,Canada 81-94), c) Monthly earnings, d) Net earnings, (Italy 79-84). 
Figure 1: Trends in Welfare Generosity.

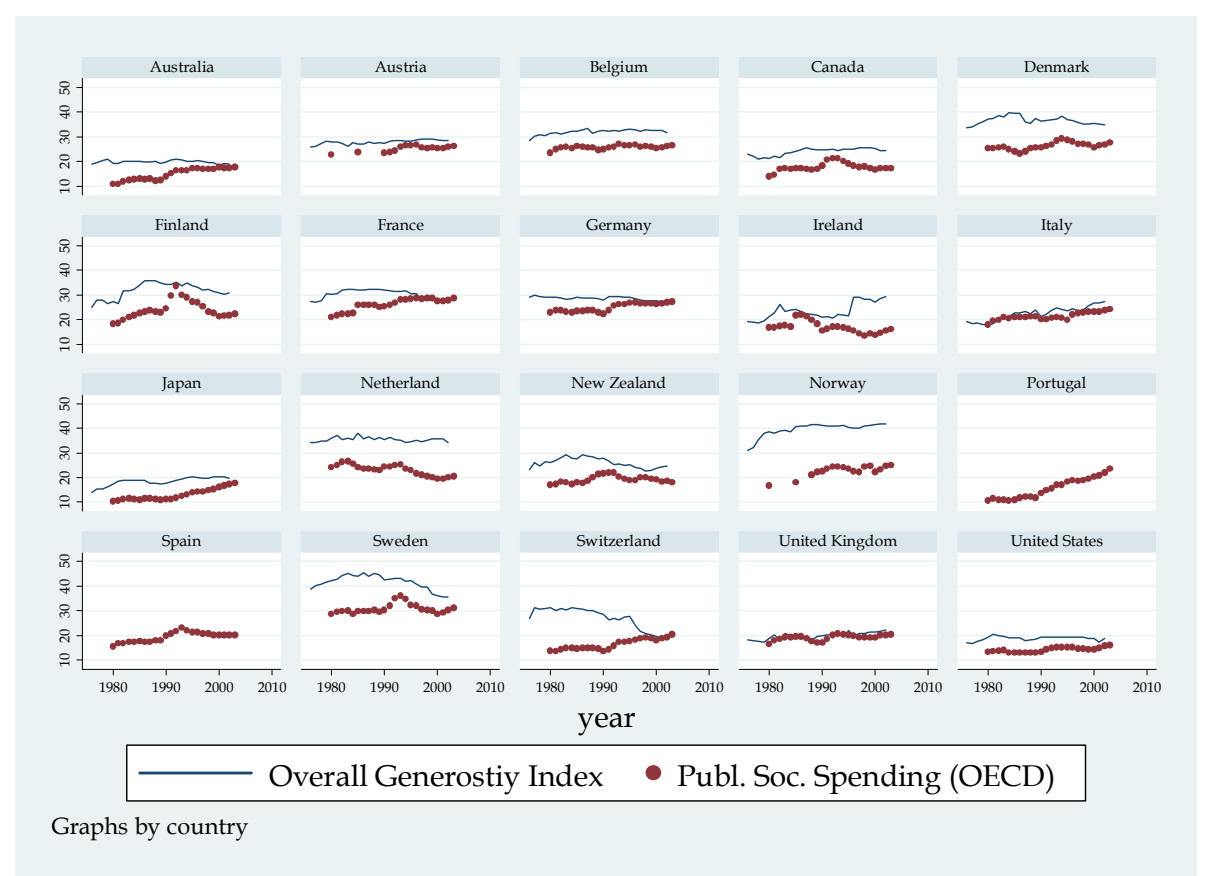

Note: Source; Overall Generosity Index: The Comparative Welfare Entitlements Dataset by Lyle Scruggs, University of Connecticut. Public Social Spending: OECD Social Expenditure Database.

source (CPD).

Bargaining indicators: Union density and bargaining coordination from 1976-2000 are obtained from: Golden, Miriam; Peter Lange; and Michael Wallerstein (2006). "Union Centralization among Advanced Industrial Societies: An Empirical Study." Dataset from http://www.shelley.polisci.ucla.edu/, version dated June 16, 2006, now available at http://dvn.iq.harvard.edu/dvn/dv/golden/faces/study/StudyPage.jsp?studyId= $636 \backslash \& t a b=f i l e s$. Union density is defined as net density (see Ebbinghaus and Visser, 2000); 2001 and 2002 values are set at 2000 level. Figures for Ireland and New Zealand from OECD Employment Outlook 2004 Table 3.3 (linearized decennial values). Coordination in bargaining is defined as the ten year average of (present and lagged) bargaining level 2 from Golden et al (2006). Bargaining level 2 is the level at which wages are determined, coded as follows:

$1=$ plant-level wage-setting

$2=$ industry-level wage-setting without sanctions

$3=$ industry-level wage-setting with sanctions

$4=$ central wage-setting without sanctions

$5=$ central wage-setting with sanctions

2001-2002 values of bargaining level 2 are set at 2000 values. Figures for Ireland and New Zealand from OECD Employment Outlook 2007 Table 3.5 Centralisation index. Workers in conflict is obtained from (CPD) Armingeon et. al. (2007), calculated as workers involved in 
Table 7: Summary Statistics

\begin{tabular}{lrr}
\hline & Mean & St.deviation \\
\hline Inequality $(\ln (\mathrm{d} 5 / \mathrm{d} 1))$ & 0.489 & 0.131 \\
Generosity $\ln (\operatorname{Index})$ & 3.28 & 0.280 \\
Openness (pct GDP) & 28.0 & 17.0 \\
log GDP per cap. & 10.13 & 0.195 \\
Tertiary ln(t/(1-t)) & -1.465 & 0.612 \\
Union Density & 38.52 & 19.53 \\
Right cabinet [0,1] & 0.339 & 0.411 \\
Share 65+ pct & 13.87 & 2.25 \\
Barg. Coordination & 3.10 & 1.18 \\
Conflict (pct) & 3.79 & 8.68 \\
\hline
\end{tabular}

The table shows summary statistics for the sample used in the preferred 3SLS specification (Table 8), $\mathrm{n}=344$.

industrial conflict, wi, in percent of civilian labor force 15-64. In the analysis including years beyond 2002 and Korea, Hungary, Spain and Portugal, variables reflecting bargaining regime, union density and workers in conflict are added on from the database of Jelle Visser (ICTWSS: Database on Institutional Characteristics of Trade Unions, Wage Setting, State Intervention and Social Pacts in 34 countries between 1960 and 2007, see http://www.uva -aias.net/208). In the one model including Korea, Hungary, Spain and Portugal, workers in conflict is imputed for Korea and Hungary, using bargaining coordination and union density.

Openness is defined as 100x(export+import)/2GDP (openk/2) from Penn World Tables, version 6.2 (see Alan Heston, Robert Summers and Bettina Aten, 2006). GDP per capita (USD, real PPP-adjusted) is taken from OECD Factbook 2006: Economic, Environmental and Social Statistics. The percent of population with tertiary education from 1990-2003 is taken from OECD Education at a Glance, various years (linearised when missing). From 1976-1989 education data is imputed using linearised values of five years figures reported in De la Fuente and Domenech (2002).

The World Value Survey, used in Table 2, is matched to our data by wave, such that respondents who have answered in wave 2 are merged into data from 1994 to 1999, wave 3 from 2000 to 2004 and so on. Indicators for Luck versus Hard Work, and General Trust are wave and country specific averages of the variables e040/10 (luck: "In the long run, hard work usually brings a better life vs. Hard work doesn't generally bring success - it is more a matter of luck and connection."), and a165=1 (trust: "Most people can be trusted" vs."Can't be too careful"). Percent immigrants are obtained from OECD International data base. Years 1994-2002.

Sources for the US-analysis 1945-2001: Social Transfers 1945-1959, Historical Statistics of the United States, Millennial edition (includes Social insurance, public aid, health and medial programs, veterans programs, housing and other social welfare programs, Tables Bf189-195/GDP Table Ca1); 1960-2001 from the OECD Lindert-Allard Data Set (2009). d9d1 from Goldin and Katz (2007) Figure 5: 1945-1960 Census data (interpolation for 45-48 (from 1939), 50- 
58, and 60-62. CPS-March data from 1963. Unemployment: 1940 Historical Statistics of the United States, Millennial edition, BA352. 1941 Interpolation. 1942-1969 Bureau of Labor Statistics, Annual household data, employment data statistics. 1970 - 2001 Source: OECD (2007), OECD Main Economic Indicators, April, Paris. Table A. Share of Population $65+$ : Historical Statistics of the United States, Millennial edition, Table Aa139. Union density: 19401950 from Historical Statistics of the US Millenial ed. Series Ba4791.Bargaining Coordination and workers in conflict are taken from the same sources as above, both are imputed when missing (before 1960) using union density and trend. College attainment: 4 years or more of college: US Census http://www.census.gov/population/www/socdemo/educ-attn.html, Linear interpolation 41-49, 51-59, 61, 63, 65, 94. Right Government: 5 year average of an (present and lagged) indicator variable for a Republican President. Source: Armingeon et al (2007). 
Appendix C: Regression tables 
Table 8: Welfare generosity and Wage Inequality: Preferred model

\begin{tabular}{|c|c|c|c|c|}
\hline & \multicolumn{2}{|c|}{ 3SLS } & \multicolumn{2}{|c|}{ Reduced form } \\
\hline & Generosity & Inequality & Generosity & Inequality \\
\hline & Coef./se & Coef./se & Coef./se & Coef./se \\
\hline \multirow[t]{2}{*}{ Inequality $\ln (\mathrm{d} 5 / \mathrm{d} 1)$} & $-.6924^{* * *}$ & & & \\
\hline & $(.1235)$ & & & \\
\hline \multirow[t]{2}{*}{ Generosity } & & $-.4628 * * *$ & & \\
\hline & & $(.1196)$ & & \\
\hline \multirow[t]{2}{*}{ Openness (pct GDP) } & $-.0017^{*}$ & $-.0018^{* *}$ & -.0006 & $-.0014^{* *}$ \\
\hline & $(.0010)$ & $(.0007)$ & $(.0011)$ & $(.0007)$ \\
\hline \multirow{2}{*}{ ln (GDP per cap.) } & $.3411^{* * *}$ & .0345 & $.4808^{* * *}$ & $-.1779 * * *$ \\
\hline & $(.0714)$ & $(.0739)$ & $(.0741)$ & $(.0473)$ \\
\hline \multirow[t]{2}{*}{ Tertiary edu. $\ln (t /(1-t))$} & $.0940 * * *$ & .0113 & $.1282^{* * *}$ & $-.0453^{* *}$ \\
\hline & $(.0261)$ & $(.0250)$ & $(.0283)$ & $(.0181)$ \\
\hline \multirow[t]{2}{*}{ Union Density (pct) } & -.0001 & $.0023^{* * *}$ & $-.0019^{*}$ & $.0034^{* * *}$ \\
\hline & $(.0009)$ & $(.0006)$ & $(.0010)$ & $(.0007)$ \\
\hline \multirow[t]{2}{*}{ Right cabinet $[0,1]$} & $-.0254^{* *}$ & & $-.0471^{* * *}$ & .0119 \\
\hline & $(.0097)$ & & $(.0126)$ & $(.0080)$ \\
\hline \multirow[t]{2}{*}{ Share $65+($ pct $)$} & $.0116^{* *}$ & & $.0173^{* * *}$ & $-.0088^{* * *}$ \\
\hline & $(.0037)$ & & $(.0039)$ & $(.0025)$ \\
\hline \multirow[t]{2}{*}{ Barg. Coordination } & & $-.0235^{* * *}$ & .0120 & $-.0367^{* * *}$ \\
\hline & & $(.0061)$ & $(.0116)$ & $(.0074)$ \\
\hline \multirow[t]{2}{*}{ Conflict (pct) } & & $.0021^{* * *}$ & $-.0024^{* * *}$ & $.0030^{* * *}$ \\
\hline & & $(.0004)$ & $(.0005)$ & $(.0003)$ \\
\hline \multirow[t]{2}{*}{ Constant } & -.0356 & $1.6479^{* *}$ & $-1.8521^{* *}$ & $2.4346^{* * *}$ \\
\hline & $(.7521)$ & $(.5087)$ & $(.7454)$ & $(.4762)$ \\
\hline p-value ctry dummies & .0000 & .0000 & .0000 & .0000 \\
\hline p-value year dummies & .0017 & .0000 & .0004 & .0000 \\
\hline Equality multiplier & \multicolumn{2}{|c|}{1.47} & & \\
\hline No. of obs. & \multicolumn{2}{|c|}{344} & \multicolumn{2}{|c|}{344} \\
\hline
\end{tabular}

Dependent variables: $\ln$ (Overall Generosity Index) and $\ln (\mathrm{d} 5 / \mathrm{d} 1)$ pre tax wages. Instruments for wage inequality are bargaining coordination, and workers in conflict. Instruments for generosity are right cabinet and percent elderly $(65+)$. All models include controls for data source, year and country dummies. 
Table 9: Excluding sub sets of countries

\begin{tabular}{lrrrrr}
\hline & \multicolumn{4}{c}{ Group of countries excluded: } \\
& America & Oceania & Large EU & Small EU & Nordic \\
& & & & & \\
\hline Inequality $\ln (\mathrm{d} 5 / \mathrm{d} 1)$ & $-.7964^{* * *}$ & $-.6293^{* * *}$ & $-.5005^{* *}$ & $-.7614^{* * *}$ & $-.8025^{* * *}$ \\
& $(.1145)$ & $(.1123)$ & $(.2313)$ & $(.1148)$ & $(.1218)$ \\
\hline \multirow{3}{*}{ Generosity } & & & & & \\
& $-.3551^{* *}$ & $-.4599^{* *}$ & $-.4402^{* * *}$ & $-.4865^{* *}$ & $-.6317^{* * *}$ \\
& $(.1662)$ & $(.1712)$ & $(.1098)$ & $(.1497)$ & $(.1286)$ \\
\hline Equality multiplier & 1.39 & 1.41 & 1.28 & 1.59 & 2.03 \\
No. of cases & 303 & 277 & 250 & 302 & 270 \\
\hline
\end{tabular}

Note: The table shows the coefficient (std.error) for $\ln (\mathrm{d} 5 \mathrm{~d} 1)$ in IV-regressions of $\ln$ (Generosity), and the coefficient (std.error) for $\ln$ (Generosity) in IV-regressions of $\ln (\mathrm{d} 5 \mathrm{~d} 1)$ in identical specification to that of the 3SLS model in Table 8, after exclusion of different sub-sets of countries. America=US,Canada; Oceania=Australia, New Zealand, Japan; LargeEU=France, Germany, Italy, the UK ; SmallEU=Austria, Belgium, Ireland, Netherlands, Switzerland; Nordic=Denmark, Finland, Norway, Sweden. Control for data set and annual wage data is based on the model on the full sample.

Table 10: Extended and sub-samples

\begin{tabular}{|c|c|c|c|c|c|c|}
\hline & \multicolumn{2}{|c|}{ OECD wages only } & \multicolumn{2}{|c|}{$\begin{array}{c}1976-2007 \\
\text { Same countries }\end{array}$} & \multicolumn{2}{|c|}{$\begin{array}{c}1976-07 \\
+4 \text { countries }\end{array}$} \\
\hline & Generosity & Inequality & Generosity*) & Inequality & Generosity*) & Inequality \\
\hline Inequality & $\begin{array}{r}-.5312^{* * *} \\
(.1115)\end{array}$ & & $\begin{array}{r}-.6219^{* *} \\
(.1904)\end{array}$ & & $\begin{array}{r}-.6636^{* *} \\
(.2101)\end{array}$ & \\
\hline Generosity (1) & & $\begin{array}{r}-.5759^{* * *} \\
(.1348)\end{array}$ & & $\begin{array}{r}-.4307^{* *} \\
(.1658)\end{array}$ & & $\begin{array}{r}-.3891^{* *} \\
(.1451)\end{array}$ \\
\hline p-value ctry & .0000 & .0000 & .0000 & .0000 & .0000 & .0000 \\
\hline p-value year & .0070 & .0240 & .0368 & .0027 & .0012 & .0000 \\
\hline Equality mult. & 1. & & 1.3 & & 1.3 & \\
\hline No. of obs. & 3 & & 41 & & 44 & \\
\hline
\end{tabular}

Dependent variables: $\ln ($ Overall Generosity Index $)$ and $\ln (\mathrm{d} 5 / \mathrm{d} 1)$. (*) Generosity is calculated from $\ln$ (public social spending) and unemployment when missing (see note 18 for details). The table shows IV estimates for the endogenous variables of the models used in table 8. All models also include all covariates of the models reported in table 8 . The first two models show results using OECD measures of wage inequality only. The next four show results from extended samples to more years and countries. To construct a generosity measure for the years from 2003-2007 and for Korea, Spain, Portugal, and Hungary, we first run a regression of $\ln$ (overall generosity index) on $\ln$ (Public Social Spending), the Unemployment rate, $\ln$ (GDP per capita) and a linear trend, and then predict generosity for the missing countryxyear cells from this equation. This means that independent variation in generosity is obtained from Public Social Spending, corrected for the level of unemployment. All in all we then have 414 from 1976 to 2007, and 447 observations in the extended data set including the four new countries. 
Table 11: Persistence and long run effects

\begin{tabular}{|c|c|c|c|c|}
\hline & \multicolumn{2}{|c|}{ Blundell Bond GMM-SYS } & \multicolumn{2}{|c|}{ IV without country fixed eff. } \\
\hline & $\begin{array}{r}\text { Generosity } \\
\text { Coef./se }\end{array}$ & $\begin{array}{r}\text { Inequality } \\
\text { Coef./se }\end{array}$ & $\begin{array}{r}\text { Generosity } \\
\text { Coef./se }\end{array}$ & $\begin{array}{r}\text { Inequality } \\
\text { Coef./se }\end{array}$ \\
\hline Inequality $\ln (\mathrm{d} 5 / \mathrm{d} 1)$ & $\begin{array}{r}-.0755^{*} \\
(.0387)\end{array}$ & & $\begin{array}{r}-.6637^{* * *} \\
(.0965)\end{array}$ & \\
\hline Lagged Inequality & & $\begin{array}{r}.8396^{* * *} \\
(.0381)\end{array}$ & & \\
\hline Generosity & & $\begin{array}{r}-.0597^{* *} \\
(.0187)\end{array}$ & & $\begin{array}{r}-.4250^{* * *} \\
(.0687)\end{array}$ \\
\hline Lagged Generosity & $\begin{array}{r}.9148^{* * *} \\
(.0320)\end{array}$ & & & \\
\hline Openness (pct GDP) & $\begin{array}{c}.0006^{* *} \\
(.0003)\end{array}$ & $\begin{array}{r}.0002 \\
(.0002)\end{array}$ & $\begin{array}{r}.0058^{* * *} \\
(.0005)\end{array}$ & $\begin{array}{r}.0031^{* * *} \\
(.0004)\end{array}$ \\
\hline ln (GDP per cap.) & $\begin{array}{r}.0257 \\
(.0276)\end{array}$ & $\begin{array}{r}.0786^{* * *} \\
(.0217)\end{array}$ & $\begin{array}{r}.4050^{* * *} \\
(.0670)\end{array}$ & $\begin{array}{r}.3799^{* * *} \\
(.0476)\end{array}$ \\
\hline Tertiary edu. $\ln (\mathrm{t} /(1-\mathrm{t}))$ & $\begin{array}{l}-.0022 \\
(.0060)\end{array}$ & $\begin{array}{r}-.0067^{*} \\
(.0036)\end{array}$ & $\begin{array}{l}.0390^{* *} \\
(.0177)\end{array}$ & $\begin{array}{r}-.0192^{*} \\
(.0115)\end{array}$ \\
\hline Union Density (pct) & $\begin{array}{r}.0000 \\
(.0001)\end{array}$ & $\begin{array}{l}.0002^{* *} \\
(.0001)\end{array}$ & $\begin{array}{r}.0024^{* * *} \\
(.0005)\end{array}$ & $\begin{array}{l}.0010^{* *} \\
(.0004)\end{array}$ \\
\hline Right cabinet $[0,1]$ & $\begin{array}{l}-.0080 \\
(.0079)\end{array}$ & & $\begin{array}{r}-.0718^{* * *} \\
(.0198)\end{array}$ & \\
\hline Share $65+(\mathrm{pct})$ & $\begin{array}{r}.0008 \\
(.0017)\end{array}$ & & $\begin{array}{r}.0249^{* * *} \\
(.0041)\end{array}$ & \\
\hline Barg. Coordination & & $\begin{array}{r}-.0093^{* *} \\
(.0030)\end{array}$ & & $\begin{array}{r}-.0613^{* * *} \\
(.0067)\end{array}$ \\
\hline Conflict (pct) & & $\begin{array}{r}-.0006^{* *} \\
(.0003)\end{array}$ & & $\begin{array}{r}-.0001 \\
(.0007)\end{array}$ \\
\hline Constant & $\begin{array}{r}.0393 \\
(.2375)\end{array}$ & $\begin{array}{r}-.4992^{* *} \\
(.1677)\end{array}$ & $\begin{array}{l}-.9956 \\
(.6538)\end{array}$ & $\begin{array}{r}-1.8427^{* * *} \\
(.4033)\end{array}$ \\
\hline Sargan p-value & .1751 & .4563 & .0000 & .0000 \\
\hline
\end{tabular}

Dependent variables: $\ln$ (Overall Generosity Index) and $\ln (\mathrm{d} 5 / \mathrm{d} 1)$. Blundell-Bond GMM-sys specification: Lagged levels of generosity and inequality dated t-2 and earlier are used as instruments for the equations in first-differences; and (correspondingly) the lagged first-differences of generosity and inequality as instruments for the equations in levels. We include the exogenous variables as well as the instruments from Table 8 (bargaining coordination, workers in conflict, right government and the share 65+) as standard instruments in the equations. Year dummies are included as instruments in the levels equation only. IV without country effects: Instruments for wage inequality are bargaining coordination and workers in conflict. Instruments for generosity are right cabinet and percent elderly $(65+)$ 
Table 12: Generosity and Wage Inequality, United States 1945-2001

\begin{tabular}{|c|c|c|c|c|c|c|}
\hline \multirow{3}{*}{ Inequality $\ln (\mathrm{d} 9 / \mathrm{d} 1)$} & \multicolumn{2}{|c|}{ IV } & \multicolumn{2}{|c|}{ IV } & \multicolumn{2}{|c|}{ Reduced form } \\
\hline & $\ln$ (Soc.sp) & Inequality & $\ln ($ Soc.sp) & Inequality & $\ln$ (Soc.sp) & Inequality \\
\hline & $\begin{array}{r}-1.5119^{* *} \\
(.6055)\end{array}$ & & $\begin{array}{r}-1.0637^{* * *} \\
(.2665)\end{array}$ & & & \\
\hline $\ln$ (Soc. Spending) & & $\begin{array}{r}-.1570^{* * *} \\
(.0397)\end{array}$ & & $\begin{array}{r}-.1623^{* * *} \\
(.0387)\end{array}$ & & \\
\hline Trend & $\begin{array}{l}.0210^{* *} \\
(.0064)\end{array}$ & $\begin{array}{l}-.0011 \\
(.0029)\end{array}$ & $\begin{array}{r}.0227^{* * *} \\
(.0061)\end{array}$ & $\begin{array}{r}-.0006 \\
(.0024)\end{array}$ & $\begin{array}{r}.0309^{* * *} \\
(.0067)\end{array}$ & $\begin{array}{r}-.0076^{* *} \\
(.0029)\end{array}$ \\
\hline $\ln$ (Unempl.) & $\begin{array}{r}.2855^{* * *} \\
(.0591)\end{array}$ & $\begin{array}{r}.0042 \\
(.0165)\end{array}$ & $\begin{array}{r}.3141^{* * *} \\
(.0361)\end{array}$ & $\begin{array}{r}.0082 \\
(.0147)\end{array}$ & $\begin{array}{r}.3488^{* * *} \\
(.0434)\end{array}$ & $\begin{array}{r}-.0498^{* *} \\
(.0186)\end{array}$ \\
\hline College (pct) & $\begin{array}{r}.0060 \\
(.0156)\end{array}$ & $\begin{array}{l}.0162^{* *} \\
(.0057)\end{array}$ & $\begin{array}{r}.0040 \\
(.0166)\end{array}$ & $\begin{array}{l}.0157^{* *} \\
(.0054)\end{array}$ & $\begin{array}{r}-.0240 \\
(.0163)\end{array}$ & $\begin{array}{c}.0204^{* *} \\
(.0070)\end{array}$ \\
\hline Eisenhower & $\begin{array}{r}-.1482^{* *} \\
(.0533)\end{array}$ & & $\begin{array}{r}-.1870^{* * *} \\
(.0292)\end{array}$ & & $\begin{array}{r}-.2295^{* * *} \\
(.0387)\end{array}$ & $\begin{array}{l}.0559^{* *} \\
(.0166)\end{array}$ \\
\hline Nixon/Ford & $\begin{array}{r}.1162^{* * *} \\
(.0266)\end{array}$ & & $\begin{array}{r}.1138^{* * *} \\
(.0246)\end{array}$ & & $\begin{array}{r}.1299^{* * *} \\
(.0343)\end{array}$ & $\begin{array}{l}-.0029 \\
(.0147)\end{array}$ \\
\hline Reagan/Bush & $\begin{array}{r}-.0538^{* *} \\
(.0202)\end{array}$ & & $\begin{array}{r}-.0539^{* * *} \\
(.0159)\end{array}$ & & $\begin{array}{r}-.0387 \\
(.0313)\end{array}$ & $\begin{array}{r}-.0105 \\
(.0134)\end{array}$ \\
\hline Age $65+$ (pct) & $\begin{array}{c}.0623^{* *} \\
(.0296)\end{array}$ & & $\begin{array}{l}.0744^{* *} \\
.0268)\end{array}$ & & $\begin{array}{r}.0790 \\
(.0484)\end{array}$ & $\begin{array}{l}-.0166 \\
(.0208)\end{array}$ \\
\hline Union Density & $\begin{array}{l}-.0179 \\
(.0222)\end{array}$ & $\begin{array}{r}-.0179^{* * *} \\
(.0030)\end{array}$ & & $\begin{array}{r}-.0179^{* * *} \\
(.0030)\end{array}$ & $\begin{array}{r}.0173 \\
(.0116)\end{array}$ & $\begin{array}{r}-.0255^{* * *} \\
(.0050)\end{array}$ \\
\hline Barg. Coord. & & $\begin{array}{r}-.0581^{* *} \\
(.0245)\end{array}$ & & $\begin{array}{r}-.0558^{* *} \\
(.0244)\end{array}$ & $\begin{array}{l}.1224^{* *} \\
(.0555)\end{array}$ & $\begin{array}{r}-.0783^{* *} \\
(.0238)\end{array}$ \\
\hline Conflict (pct) & & $\begin{array}{r}-.0013 \\
(.0035)\end{array}$ & & & $\begin{array}{r}-.0026 \\
(.0101)\end{array}$ & $\begin{array}{r}-.0037 \\
(.0043)\end{array}$ \\
\hline Constant & $\begin{array}{r}2.8165^{* *} \\
(1.4109)\end{array}$ & $\begin{array}{r}1.9225^{* * *} \\
(.1184)\end{array}$ & $\begin{array}{r}1.6499^{* * *} \\
(.2447)\end{array}$ & $\begin{array}{r}1.9121^{* * * *} \\
(.1147)\end{array}$ & $\begin{array}{l}-.2173 \\
(.6134)\end{array}$ & $\begin{array}{r}2.1542^{* * *} \\
(.2634)\end{array}$ \\
\hline Hansen J, p-value & .4834 & .1247 & .2917 & .1603 & & \\
\hline Cragg-Donald F & 5.44 & 16.66 & 36.89 & 17.84 & & \\
\hline No. of cases & 57 & 57 & 57 & 57 & 57 & 57 \\
\hline
\end{tabular}

Dependent variables: $\ln$ (Social Spending pct gdp) and $\ln (\mathrm{d} 9 / \mathrm{d} 1)$ male pre tax wages. Instruments for wage inequality included in the first model are bargaining coordination and the share of workers in conflict, the next model replace workers in conflict with union density as an instrument. Bargaining coordination and workers in conflict are imputed before 1960, using union density. Instruments for generosity included in the IV specifications are dummies for the republican presidential periods: Eisenhower, Nixon-Ford and Reagan-Bush, and the percent of elderly $(65+)$ in the population. Statistics robust to heteroscedasticity and autocorrelation. 